\title{
Hesiod and the Ancient Biographical Traditions
}

\section{Citation}

Nagy, Gregory. 2009. Hesiod and the Ancient Biographical Traditions. In The Brill Companion to Hesiod, ed. F. Montanari, 271-311. Leiden: Brill, 2009.

\section{Published Version}

doi:10.1163/9789047440758_012

\section{Permanent link}

http://nrs.harvard.edu/urn-3:HUL.InstRepos:15550088

\section{Terms of Use}

This article was downloaded from Harvard University's DASH repository, and is made available under the terms and conditions applicable to Other Posted Material, as set forth at http:// nrs.harvard.edu/urn-3:HUL.InstRepos:dash.current.terms-of-use\#LAA

\section{Share Your Story}

The Harvard community has made this article openly available.

Please share how this access benefits you. Submit a story.

Accessibility 


\section{Hesiod and the Ancient Biographical Traditions}

\section{Gregory Nagy}

[ [This essay is an online version of an original printed version that appeared in The Brill Companion to Hesiod, ed. F. Montanari, A. Rengakos, and Ch. Tsagalis (Leiden 2009) 271-311. In this online version, the original page-numbers of the printed version are indicated within braces (" $\{$ " and " $\}$ "). For example, "\{271|272\}" indicates where p. 271 of the printed version ends and p. 272 begins.]]

\section{Introduction}

This presentation examines what is said about the life and times of the poet Hesiod in two sets of ancient sources. The first set is the actual poetry ascribed to Hesiod, primarily the Theogony and the Works and Days. As for the second set, it consists of ancient texts that were external to that poetry. ${ }^{1}$

On the basis of passages in Hesiodic poetry that refer to Hesiod (Theogony 22-34; Works and Days 27-41, 646-662), the following "biography" has been reconstructed in an introductory work intended for nonexperts:

Out of these passages a skeletal biography of Hesiod can be constructed along the following lines. The son of a poor emigrant from Asia Minor, born in Ascra, a small village of Boeotia, Hesiod was raised as a shepherd, but one day, without having had any training by human teachers, he suddenly found himself able to produce poetry. He attributed the discovery of this unexpected capability to a mystical experience in which the Muses themselves initiated him into the craft of poetry. He went on to achieve success in poetic competitions at least once, in Chalcis; unlike his father, he did not have to make his living on the high seas. He quarreled with his brother Perses about their inheritance, accusing him of laziness and injustice. ${ }^{2}$

In terms of such a reconstruction, this "biography" of Hesiod is distinct from the stories about Hesiod that we find in ancient texts external to Hesiodic poetry. Supposedly, those external stories "can easily be dismissed as legends, possessing little or no historical value."

Such a distinction between "biography" and "legends" is untenable, however, as we can see from testing the applications of these terms. $\{271 \mid 272\}$

\footnotetext{
${ }^{1}$ Both sets of sources are analyzed in Nagy 1990b:36-82.

${ }^{2}$ Most 2006a:xii-xiii.

${ }^{3}$ Most 2006a:xvi.
} 


\section{"Biography" of Hesiod}

First, let us test the term "biography" as applied to what is said about Hesiod in Hesiodic poetry. This term suits the argument that we need not "disbelieve" Hesiod in his role as the first-person narrator of episodes in the Theogony and the Works and Days. In terms of such argumentation, these episodes are "biographical" in the sense that they are "autobiographical." And, as "autobiographical" episodes, they are supposed to be at least potentially believable. Even in the case of episodes that seem unbelievable, they are supposedly still believable on the grounds that they are "autobiographical."

A prime example of such "biography" is the episode in the Hesiodic Theogony (22-34) where the figure of Hesiod declares that the Muses, as goddesses of poetry, initiated him into their craft. Even in the case of this episode, it has been argued, we do not have to "disbelieve" Hesiod-so long as we believe him in the case of other episodes that are more believable. Supposedly, "Hesiod himself seems to regard all these episodes as being of the same order of reality, and there is no more reason to disbelieve him in the one case than in the others." 5

In terms of such argumentation, we may believe Hesiod because he himself believed that he was inspired by the Muses: "Apparently, Hesiod believed that he had undergone an extraordinary experience, as a result of which he could suddenly produce poetry." Among the factors contributing to Hesiod's belief, if we follow this line of reasoning, was "the awareness within himself of a new ability to compose poetry about matters past and future (hence, presumably, about matters transcending the knowledge of the human here and now, in the direction of the gods who live forever), which he interprets as a result of the Muses having breathed into him a divine voice."

This line of reasoning is based on an assumption. The "reality" to be found in Hesiodic poetry is assumed to be the experiential world of a person named Hesiod who lived at a given point in history. It is as if such a reality could be reconstructed by taking literally whatever the figure of Hesiod says about himself in Hesiodic poetry. \{272|273\}

But the fact is, the primary "order of reality" to be found in Hesiodic poetry is not Hesiod the person but the poetry itself. It was this poetry that brought to life the person that is Hesiod.

What, then, can we say about the reality that was Hesiodic poetry? Let us begin with two observations about two generally recognized historical facts about the making of Hesiodic poetry:

\footnotetext{
${ }^{4}$ Most 2006a:xviii, xix.

${ }^{5}$ Most 2006a:xiii.

${ }^{6}$ Most 2006a:xiii.

${ }^{7}$ Most 2006a:xiv.
} 
1. Like Homeric poetry, Hesiodic poetry was basically oral poetry. I quote this succinct formulation: "Both Homeric poetry and Hesiod's seem to presuppose a tradition of fully oral poetic composition, performance, reception, and transmission."

2. Like Homeric poetry, Hesiodic poetry was "widely disseminated" in the ancient Greekspeaking world (as is most evident in the case of the Theogony).

The second of these two observations needs further clarification. The dissemination of Homeric and Hesiodic poetry, it has been claimed, was a result of textualization..$^{10}$ In terms of this claim, the new technology of alphabetic writing had been used to write down both Homeric and Hesiodic poetry, as early as the eighth century BCE. ${ }^{11}$ There is simply no evidence, however, for the use of writing to record Homeric and Hesiodic poetry as integral compositions in such an early period. ${ }^{12}$ So, the claim that Homeric and Hesiodic compositions were widely disseminated as texts in the eighth century BCE is untenable.

The same can be said more generally about the archaic era extending from the eighth through the sixth century BCE: in this era, there is no evidence for any widespread dissemination of any texts of poetry. ${ }^{13}$

There is an alternative way, however, to explain the dissemination of Homeric and Hesiodic poetry during this archaic period. In terms of this alternative explanation, the two observations about (1) Homeric and Hesiodic poetry as oral poetry and (2) the dissemination of Homeric $\{273 \mid 274\}$ and Hesiodic poetry can be integrated into a unified formulation. To put it most simply, Homeric and Hesiodic poetry were disseminated as oral poetry.

This unified formulation is based on (1) general observations about the factor of dissemination in oral poetry and (2) specific observations about the dissemination of Homeric and Hesiodic poetry as oral poetry: ${ }^{14}$

1. In oral poetry, composition and performance are aspects of the same process. So, when a composition is performed at different times and in different places, it can be recomposed in the process of composition-in-performance. And the ongoing recomposition-in-

\footnotetext{
${ }^{8}$ Most 2006a:xix-xx. Regrettably, Most's discussion makes no reference to the foundational work of Lord 1960/2000 on oral poetics.

${ }^{9}$ Most 2006a:xxxiv.

${ }^{10}$ Most 2006a:xxxiv-xxxvi.

${ }^{11}$ Most 2006a:xx-xxii.

${ }^{12}$ On the poetics of epigrams, which are attested already in the eighth century BCE, see Nagy 1996b:14, 35-36: as it is argued there, the poetry of epigrams shows a clear separation between the processes of composing and inscribing.

${ }^{13}$ Nagy 1996b:34-37.

${ }^{14}$ What follows is a summary of the argumentation in Nagy 1990b:38-47, relying on the fundamental work of Parry (collected writings first published in 1971) and Lord (1960/2000).
} 
performance needs to be viewed diachronically as well as synchronically. ${ }^{15}$ From a synchronic point of view, the poet who performs a poem can claim to own it as his own composition in the process of recomposing it in performance. From a diachronic point of view, however, the ownership can readily be transferred from poem to poem, from poet to poet. And such transference can promote the dissemination of both the poetry and the name of the poet.

2. In the archaic period of Hellenic civilization extending roughly from the eighth through the sixth century $\mathrm{BCE}$, there already existed forms of oral poetry that corresponded to what was later known as Homeric and Hesiodic poetry. With the passage of time, the dissemination of these forms of poetry became more and more widespread throughout the communities of the Hellenic world. This process of ever widening dissemination, in the context of ongoing recomposition-in-performance, can be described as pan-Hellenization. Correspondingly, the poets who were identified with these forms of poetry, Homer and Hesiod, became more and more pan-Hellenic.

The term pan-Hellenic is derived from the ancient Greek compound noun pan-Hellenes 'all

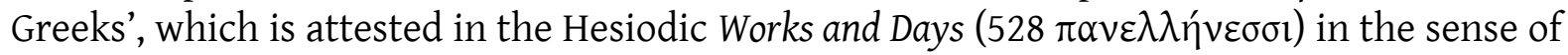

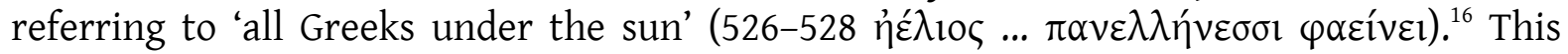
$\{274 \mid 275\}$ archaic use of the compound noun pan-Hellenes in the absolutizing sense of 'all Greeks' helps explain the later use of the non-compound noun Hellenes 'Hellenes' to mean 'Greeks'; earlier, that noun Hellenes had been used to designate a sub-set of Greeks dwelling in Thessaly rather than any full complement of Greeks. As the linguistic evidence shows, the accentuation of the non-compound noun Hellenes should be non-recessive ( $\left.{ }^{*} E \lambda \lambda \tilde{\eta} v \varepsilon \varsigma\right)$, not recessive ("E $\lambda \lambda \eta \vee \varepsilon \varsigma$ ), and the fact that Hellènes acquired an innovative recessive accentuation proves that its innovative meaning of 'Greeks' was predicated on the accentuation of the compound noun pan-Hellenes in the absolutized sense of 'all Greeks'. ${ }^{17}$ In other words, the linguistic evidence shows that the non-compound noun Hellenes acquired the meaning of 'Greeks' from the built-in politics of the compound noun pan-Hellenes, the basic meaning of which can be paraphrased this way: Hellenes (as a subset of Greeks) and all other Greeks (as a notionally complete set of Greeks). ${ }^{18}$

When I said earlier that Homer and Hesiod "became more and more pan-Hellenic," I was using the term pan-Hellenic in a relativized sense, despite its inherently absolutized meaning as 'common to all Greeks'. To relativize pan-Hellenic is to recognize that the panHellenization of Homer and Hesiod, just like other aspects of pan-Hellenism, cannot be described in absolute terms of universalization. Despite the totalizing ideology implicit in the term pan-Hellenic, the pan-Hellenization of Homer and Hesiod was not an absolute: it was merely a tendency toward a notional absolute..$^{19}$ And, just as the concept of pan-Hellenism was in fact relative, so also the concept of a pan-Hellenic Homer or a pan-Hellenic Hesiod was

\footnotetext{
${ }^{15}$ On the distinction between synchronic and diachronic approaches to the analysis of a given structure in the study of oral poetics: Nagy 2003:1.

${ }^{16}$ Nagy 1990b:37.

${ }^{17}$ Chantraine DELG s.v. "E $\lambda \lambda \eta v \varepsilon \varsigma$.

${ }^{18}$ Nagy 1996b:39n40.

${ }^{19}$ Nagy 1996b:38-40.
} 
relative, since it depended on the various appropriations of these poetic figures by the various Greek communities that claimed them as their own.

The episode about Hesiod's initiation by the Muses in the Theogony dramatizes the panHellenization of Hesiodic oral poetry. In the Theogony (54) these Muses are pictured as the daughters of the goddess Mnêmosune 'Memory', who is the absolutized concept of poetic memory. By extension, the Muses are absolutized as the sources of this memory for the poet of the Theogony. And, by further extension, the poet's memory is itself absolutized and thereby pan-Hellenized, since the Muses $\{275 \mid 276\}$ are said to give him an absolute authority expressed in terms of an absolute truth value..$^{20}$

The word for this truth value is alethea, which can be translated as 'true things'. In the Hesiodic Theogony (28), the Muses are quoted as saying to Hesiod that they know how to speak alèthea 'true things'. But this word alèthea means far more than 'true things'. The root lèth- of aletthea means 'forget', which is the opposite of the root mne- meaning 'remember'-as in the word mnēmosune 'memory', which is also the name of the goddess who is mother of the Muses. Basically, the negativized adjective alèthes- means 'unforgettable', so that alèthea means, literally, 'unforgettable things'. ${ }^{21}$ Semantically, what is unforgettable is not just memorable, which would be a relative thing. More than that, what is unforgettable is an absolute thing. It is something that is absolutely memorable. It is therefore the absolute truth. The 'true things' that Hesiod learns from the Muses are absolutely memorable because they are absolutely unforgettable. ${ }^{22}$ Here are the relevant words of the Muses themselves, as quoted by the figure to whom they are said to be speaking, Hesiod:

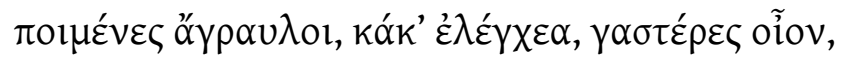

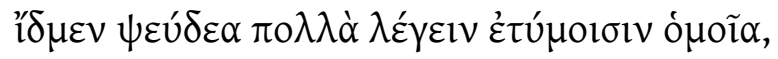

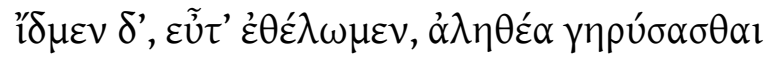
Shepherds living in the fields, base objects of reproach, mere bellies! We know how to say many falsehoods [pseudea] that look like genuine things, but we can also, whenever we are willing, proclaim true things [alèthea].

Hesiod Theogony 26-28

There are comparable passages in the Homeric Odyssey that help us understand the poetic agenda of what the Muses are quoted as saying to Hesiod. One such passage (xiv 124125) tells of wanderers who can tell stories as told by oral poets and who 'are unwilling' (oud'

\footnotetext{
${ }^{20}$ Nagy 1992, 1996c.

${ }^{21}$ Detienne 1994:5-31/1996:15-33, with a critique of Heidegger's interpretation of alèthea/aletheia and with updated polemics.

${ }^{22}$ Nagy 1996b:124-128.
} 
ethelousin) to tell alèthea 'true things'; instead, they pseudontai 'tell falsehoods' to their audiences because they need to eat in order to survive:

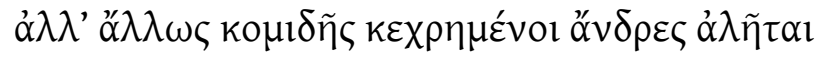

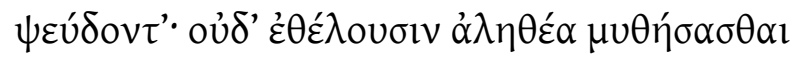
$\{276 \mid 277\}$

It's no use! Wanderers in need of food tell falsehoods, and they are unwilling to tell true things [alēthea].

Odyssey xiv 124-125

So also in the case of the wandering Odysseus himself, he too behaves like such a wandering oral poet while being hosted as an unidentified guest at the court of Alkinoos the king of the Phaeacians. Before Odysseus as the unknown wanderer tells his audience of Phaeacians the entertaining tales of his woeful adventures, he asks his hosts to let him eat first (Odyssey vii 215-221), since his gastēr 'belly' (216) is making him 'forget' those tales of his, lèth-anei (221), until it is filled with food. In his role as the oral poet of his own adventures, Odysseus is like wandering oral poets who 'are unwilling' (oud' ethelousin) to tell alethea 'true things' because they need to feed their bellies in order to survive and must therefore tell things that their audiences want to hear, which are falsehoods (again, Odyssey xiv 124-125).

By contrast, the Muses of Hesiod will 'willingly' (ethelōmen) tell him aletthea 'true things' (again, Theogony 28). We see here what amounts to a manifesto of pan-Hellenic poetry, in that the poet Hesiod is now to be freed from being a mere 'belly', which is what the Muses call him derisively when they first address him (Theogony 26). Hesiod is now to be freed from having to tell the kinds of things he would tell in order to feed his belly for survival. Those kinds of things are pseudea polla 'many false things' (Theogony 27). And a sign of the falseness of those things is that they are many, multiple. Those many false things merely look like etuma 'genuine things', to be contrasted with the unique things that are genuinely alethea 'true'. Once Hesiod is initiated by the Muses, he is to be freed from having to say things that would please only his local audiences who are rooted in their local poetic traditions: those multiple local poetic traditions are pseudea 'false things' in face of the unique alethea 'true things' that the Muses impart specially to Hesiod. This uniqueness is a sign of the pan-Hellenism claimed by Hesiodic poetry, which is capable of achieving something that goes beyond the reach of multiple local poetic traditions. ${ }^{23}$

And who are these Muses who initiate Hesiod, thereby transforming him from a humble shepherd into a poet of pan-Hellenic stature? Like Hesiod, whose local origins are rooted in the region of Mount Helicon in Boeotia, these goddesses are local to the same region. At the beginning $\{277 \mid 278\}$ of the Hesiodic Theogony (1-8), the Muses are pictured as singing and dancing in the heights of Mount Helicon. But they too, like Hesiod, are transformed. In the

\footnotetext{
${ }^{23}$ Nagy 1990b:45.
} 
process of initiating Hesiod, they are relocated from Mount Helicon in Boeotia to Mount Olympus in Macedonia. And, in the process of being relocated, the Heliconian Muses are transformed into the Olympian Muses.

After the episode about Hesiod's initiation in the foothills of Mount Helicon is completed (Theogony 22-35), we find that the Muses can now be relocated to Mount Olympus $(37,42)$, and, in fact, they are already described as Olympian Muses at the commencement of the episode about the poet's initiation (25). In the process of initiating Hesiod as a pan-Hellenic poet, these goddesses can begin their transformation from Heliconian into Olympian Muses. Just as we saw them descending from Helicon (9), we now see them ascending to Olympus (68). And, as Olympian Muses, they achieve pan-Hellenic status, just as Hesiod achieves panHellenic status as a poet. The comparative evidence from the Homeric Hymns is decisive in this regard: in these Hymns, the ascent of gods and goddesses to the heights of Olympus is tantamount to achieving pan-Hellenic status. ${ }^{24}$

As we see, then, from the internal evidence of Hesiodic poetry, the episode about the initiation of Hesiod by the Heliconian Muses is far more than a story about a poet's personal experience. It is a story that universalizes the figure of Hesiod as poet, making him a generic representative of a pan-Hellenic form of poetry.

In this light, the episode about Hesiod's initiation by the Muses seems more programmatic than "biographical."

\section{“Legends" of Hesiod}

Having tested the term "biography" as applied to what we find in Hesiodic poetry about Hesiod, we turn next to the term "legends" as applied to what we find in texts that are external to Hesiodic poetry. By contrast with the "biography" of Hesiod that is internal to Hesiodic poetry, whatever stories we find in the external texts are supposedly "legends." These stories about the life and times of Hesiod, which are "full of a wealth of circumstantial detail concerning his family, birth, poetic career, character, $\{278 \mid 279\}$ death, and other matters," are supposedly the result of "a well-attested practice of extrapolating from the extant poetic texts"; as such, these stories "probably reflect very little about the real person Hesiod." 25

According to this point of view, then, the "legends" represented by these external stories provide no evidence about the "biography" of Hesiod. They provide evidence only about the "reception" of Hesiodic poetry ${ }^{26}$ As we will see, however, there is evidence for such "reception" even in the internal stories, that is, in the so-called "biography" of Hesiod that is

\footnotetext{
${ }^{24}$ Nagy 1990b:56-57.

${ }^{25}$ Most 2006a:xvi.

${ }^{26}$ Most 2006a:xvi-xvii.
} 
internal to Hesiodic poetry. And, as we will also see in general, there is no justification for making a distinction between a "biography" of Hesiod that was internal to Hesiodic poetry and the "legends" about Hesiod that were external to it.

In any case, both of these terms, "biography" and "legends," are inadequate for describing the stories about Hesiod. In the case of "biography," the term is inadequate because it implies the existence of a documentary text that narrates verifiable historical facts about the life and times of a historical person. In the case of "legends," the term is inadequate because it implies the exact opposite of historical facts. It is as if the stories about the life and times of Hesiod had no historical value at all.

But the real historical facts are the stories themselves, which are artifacts that have their own historical reality. For an objective analysis of these stories in their historical contexts, the point of reference must be the real world in which the stories were told, not the artificial world as created by the artifice that went into the telling of the stories.

From here on, I will refrain from using either term, "biography" or "legends," in referring to stories about the life and times of Hesiod. For the moment, it is preferable to use a more neutral term, such as "stories."

\section{"Life of Hesiod" and "Life of Homer" stories as myths}

The artifice of telling stories about Hesiod was not a matter of fiction. A fiction is conventionally understood as something invented or "made up" by an individual - something that is therefore unreal. By contrast, the various stories telling about the life of Hesiod were telling something real about a reality. That reality was the poetry of Hesiod. And the art of telling about that reality was a matter of telling a myth, which was the myth of $\{279 \mid 280\}$ Hesiod. And the same can be said, as we will see later, about the various stories telling about the life of Homer: they too were telling a myth, which was the myth of Homer. Hereafter, I will use this word myth in referring to the "Life of Hesiod" and "Life of Homer" stories.

In using this word myth, I have in mind the meaning of the Greek word from which it derives, muthos, which in its earlier phases was understood to be the telling of something that is real - real not only for an individual but also, collectively, for society. Such a usage of the noun muthos (and of the derivative verb mutheîsthai) is most evident in the diction of Homeric poetry - and likewise in Hesiodic poetry, as in the Theogony (24). ${ }^{27}$

\footnotetext{
${ }^{27}$ Nagy 1996b:119-127, following Martin 1989. See also Nagy p. 124 on the textual variants

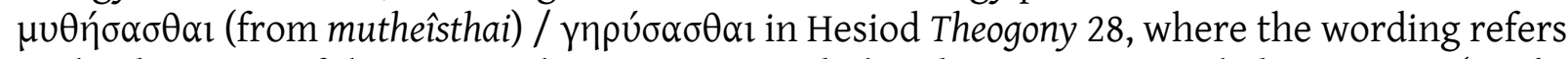
to the discourse of the Muses who inspire Hesiod; that discourse is signaled as a $\mu \tilde{v} \theta 0 \varsigma$ (muthos) in Theogony 24. See also Martin p. 105, with reference to Hesiod Theogony 28.
} 
Only in its later phases was the word muthos understood to be the telling of something that is unreal, as when Plato's Socrates speaks of the muthoi 'myths' told by Homer and Hesiod as pseudeis 'false' (Republic 2.377d-378c). Plato is assuming here, we should note, that "the poet takes on the role of the speaker of his poem." ${ }^{28}$ What Homer and Hesiod are saying is what their poetry is saying.

In terms of the earlier understanding of the word muthos, by contrast, the myths told by Homer and Hesiod were true, not false. And the same goes for myths told about Homer and Hesiod: they too were true, not false. A case in point is the use of the word muthos in the Hesiodic Theogony (24) with reference to what the Muses are quoted as saying to Hesiod in the three verses I already quoted (26-28): these verses spoken by the Muses are a notional retelling by Hesiod of the muthos told by the goddesses (24). This muthos, then, is not only about the Muses in the act of speaking to Hesiod: it is also about Hesiod. Because the Muses are speaking to him and thereby initiating him as a poet, Hesiod becomes part of the muthos - part of the true story.

\section{A "Life of Hesiod" myth embedded in Hesiodic poetry}

This story that tells about the initiation of Hesiod by the Muses is thus a myth in the older sense of the word muthos - in the sense of a true story. And this myth, embedded in Hesiodic poetry, is the most basic of all the $\{280 \mid 281\}$ "Life of Hesiod" myths. That is because this story defines Hesiod in terms of his relationship to the Muses.

As we have already seen, the story tells how the Muses make Hesiod a pan-Hellenic poet. He achieves this status because the Heliconian Muses become Olympian Muses in the process of initiating him. And these goddesses become Olympian, as we have also seen, by virtue of the fact that the Theogony actually shows them ascending to take their rightful place on Mount Olympus, just as other gods and goddesses become Olympian by virtue of the fact that they too are shown ascending to Mount Olympus. We have already noted the myths that show such Olympian ascents in the Homeric Hymns.

Such myths about the achievement of Olympian status by a special grouping of gods are presupposed in the Homeric Iliad and Odyssey, where the pan-Hellenic status of the Olympian gods is marked by their location on Mount Olympus. In the case of the Homeric Muses, their location on Mount Olympus is made explicit when Homer as speaker invokes them all together in the Iliad (II 484): they are said to have their residences on the holy mountain ('O $\lambda u ́ \mu \pi \iota \alpha$ $\left.\delta \omega \dot{\mu} \mu \alpha \tau^{\prime} \xi^{\prime} \chi 0 v \sigma \alpha \iota\right)$.

We have already seen that the pan-Hellenization of Hesiodic poetry, as defined by the Olympian Muses, can be explained in terms of oral poetry. But there is still a question about

\footnotetext{
${ }^{28}$ Martin 1989:235.
} 
the myth that signals this pan-Hellenization in terms of Hesiod's relationship with the Muses. Can this myth be explained in terms of oral poetry as well?

We find something close to a definitive answer in the succinct formulation I quoted earlier: "Both Homeric poetry and Hesiod's seem to presuppose a tradition of fully oral poetic composition, performance, reception, and transmission." ${ }^{29}$

In the case of Hesiodic poetry, we can see references to all four of these aspects of oral poetry: composition, performance, reception, and transmission. These four aspects, as we will now see, are all at work in the myth about the poet's initiation by the Muses, as embedded in the Hesiodic Theogony. $\{281 \mid 282\}$

\section{composition and performance}

In the Theogony, references to the composition and performance of Hesiodic poetry are expressed by way of picturing the Muses as the models of Hesiod. The Muses 'teach their

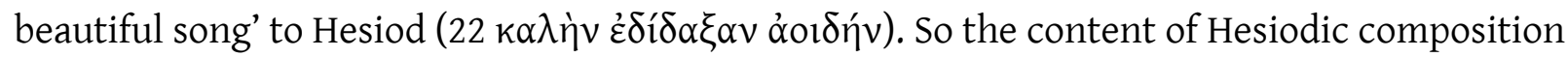
emanates from them. And that content is passed on to Hesiod when the Muses literally

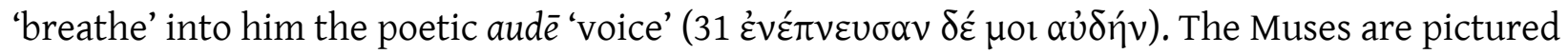
as actually starting the song to be sung by Hesiod, which is their own song (105-112). Their song is a theogony in its own right, in that they sing the genesis of the gods (105 $\dot{\alpha} \theta \alpha v \alpha$ q́ $\tau \omega v$

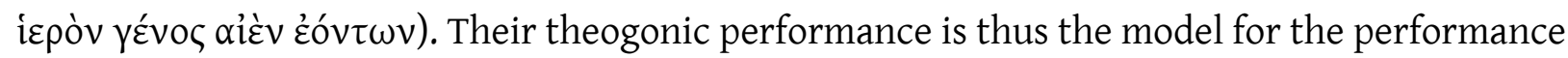
of the Hesiodic Theogony. Singing the genesis of the gods, they show Hesiod how to sing it in his own right, specifying that he should be mindful of their own priority as he sings their own

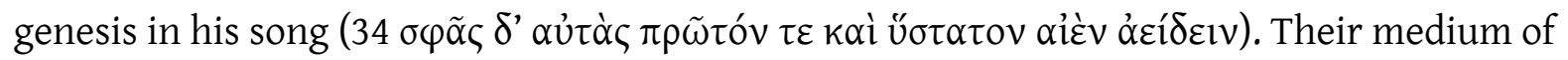
performance, however, is different from the medium of Hesiod: the Muses perform their theogonic song in the mode of a khoros 'chorus' of local goddesses (7 xopoúc), singing and dancing in a locale sacred to them, Mount Helicon $(3-4,70)$.

\section{reception and transmission}

I use the term reception here not in the narrow sense that applies in studies of literature, where this term conventionally refers to whatever happens after a given piece of literature is composed for transmission to the public. A broader sense of the term is needed when we are dealing with literary traditions that stem from oral traditions, as in the case of Hesiodic poetry.

How, then, are we to understand the phenomenon of reception in oral traditions? The answer has to do with the transmission of composition by way of performance. In any oral tradition, as we saw earlier, the process of composition is linked to the process of performance, and any given composition can be recomposed each time it is performed. The performer who

\footnotetext{
${ }^{29}$ Most 2006a:xix-xx.
} 
recomposes the composition in performance may be the same performer who composed it earlier, or it may be a new performer, even a succession of new performers. The point is, such recomposition-in-performance is the essence of transmission in oral traditions. ${ }^{30}\{282 \mid 283\}$

This kind of transmission is the key to a broader understanding of reception. Unlike what happens in literature, where reception by the public happens only after a piece of literature is transmitted, reception in oral traditions happens during as well as after transmission. That is because the process of composition in oral traditions allows for recomposition on each new occasion of performance for a public that sees and hears the performer. In oral traditions, there is an organic link between reception and performance, since no performance can succeed without a successful reception by the public that sees and hears the performer or performers.

The link between reception and performance affects the actual content of the composition performed before a given public. That is because the performance of a given composition can speak about itself. For example, the performance can say things about the context of performance or even about the performer or performers. What is said, however, will be subject to change from performance to performance, and such change can actually affect the content of the composition by way of recomposition-in-performance. ${ }^{31}$

In terms of this broader understanding of reception, the storytelling of the various "Life of Hesiod" myths is grounded in Hesiodic poetry itself, which is oral poetry. What Hesiodic poetry says about itself, as in the case of the episode about Hesiod's initiation by the Muses, is already a "Life of Hesiod" myth in the making.

Earlier, we noted the various references in the Hesiodic Theogony to the transformation of the Muses from Heliconian to Olympian status. And we also noted that this transformation reflects the pan-Hellenization of Hesiodic poetry, which is parallel to the pan-Hellenization of the Heliconian Muses who initiated Hesiod. By now we can see that the story of this panHellenization, as expressed by the myth about Hesiod's initiation by the Muses, is the story of the reception and transmission of Hesiodic poetry.

\section{A comparable "Life of Homer" myth embedded in Homeric poetry}

In Homeric poetry, there is an episode containing a comparable reference to reception and transmission. It takes place in the Homeric Hymn to Apollo. This episode, as we are about to see, is an embedded myth that tells about Homer's encounter with the Delian Maidens, which is a close parallel to the embedded myth $\{283 \mid 284\}$ that tells about Hesiod's initiation by the

\footnotetext{
${ }^{30}$ Nagy 2004 b, with reference to the transmission of poetry attributed to Alcaeus.

${ }^{31}$ Nagy 1996a:207-225.
} 
Muses. By telling about Homer's encounter with these Delian Maidens, this myth is also telling about the pan-Hellenic reception and transmission of Homeric poetry as oral poetry. ${ }^{32}$

In the Homeric Hymn to Apollo, the poet who speaks is imagined as Homer himself. In the ancient world, as we know from the explicit testimony of Thucydides (3.104.4), Homer was recognized as the poet of this Hymn. So we have external evidence for thinking of Homer as the poet of the Homeric Hymn to Apollo. But the point is, we also have internal evidence: as we are about to see, the identity of Homer in this Hymn is determined by his interaction with the Delian Maidens.

These Maidens in the Homeric Hymn to Apollo are parallel to the Muses in the Hesiodic Theogony. We have seen Hesiod, as poet of the Theogony, interacting with a chorus of Heliconian Muses. Now we will see Homer, as poet of the Hymn to Apollo, interacting with a chorus of Delian Maidens.

In the Homeric Hymn to Apollo, the Delian Maidens are described as the therapnai 'attendants' of the god Apollo (157), and they are addressed by the poet of the Hymn with the hymnic salutation khairete 'hail and take pleasure' (166), in conjunction with the god Apollo (165). With his salutation of khairete (166), the poet is asking the Delian Maidens to accept the kharis 'favor' of his song and to give him their 'favor', their kharis, in return. The hymnic salutation khaire / khairete is used in the Homeric Hymns to address the given god / gods presiding over the performance of each given hymn. ${ }^{33}$ Similarly in the Hesiodic Theogony, the figure of Hesiod addresses the Muses with the hymnic salutation khairete (104) in the context of naming them, in conjunction with Apollo, as the divine sources of poetic power (94-95).

There is a symmetry here between the poet of the Homeric Hymn to Apollo and Hesiod as the poet of the Theogony. I focus on the fact that the Delian Maidens are addressed with the hymnic salutation khairete in the Homeric Hymn to Apollo (166) just as the Olympian Muses are addressed with the hymnic salutation khairete in the Theogony (104). This symmetry indicates that the poet of the Homeric Hymn is in effect addressing the local Muses of Delos, who are divine in their own right. It is not a contradiction, however, to maintain that the Delian Maidens are simultaneously envisioned as members of a local khoros 'chorus' of girls \{284|285\} or women, since the role of divinity can be appropriated by members of a chorus during choral performance..$^{34}$ That is to say, the Delian Maidens as a choral ensemble can re-enact the local Delian Muses.

\footnotetext{
${ }^{32}$ What follows corresponds to paragraphs 5-11 in Nagy 2006:319-321.

${ }^{33}$ Nagy 1990b:58.

${ }^{34}$ Nagy 2006:317, 319-320; also Calame 2001:30, 104, 110. Thucydides (3.14.5) refers to the chorus of Delian Maidens as gunaikes ‘women'; accordingly, it may be too restrictive to say
} 
The designation of the Delian Maidens as therapnai 'attendants' of the god Apollo in the Homeric Hymn to Apollo (157) is comparable to the designation of the generic aoidos 'singer' as

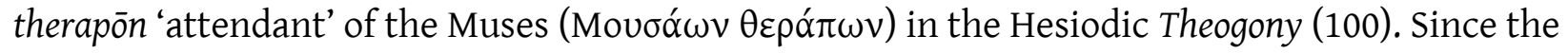
feminine form therapnē 'attendant' is related to the masculine therapōn 'attendant', I suggest that the Delian Maidens as performers are surrogates of Apollo and, by extension, of his choral ensemble of Muses, just as the generic aoidos 'singer' in the Theogony is a surrogate of the Muses, and by extension, of their choral leader Apollo.

The poet's dramatized encounter with the Delian Maidens in the Homeric Hymn to Apollo is parallel to Hesiod's dramatized encounter with the local Muses of Mount Helicon in the Hesiodic Theogony (22-34), which leads to the transformation of their local theogony into the pan-Hellenic Theogony sung by Hesiod - and to their own transformation into the pan-Hellenic Muses of Mount Olympus (verses 52 and thereafter). ${ }^{35}$ The pan-Hellenization of the Heliconian Muses is a matter of reciprocation: they are transformed into Olympian Muses because they transform Hesiod, who is implicitly a generic aoidos 'singer' and master of poetic kleos 'fame' (Theogony 99-101). They transform Hesiod into a pan-Hellenic figure in his own right, who articulates a single Theogony that notionally supersedes all other potential theogonies in its truth value (22-34) ${ }^{36}$ Further, the local humnos of the Heliconian Muses has been transformed into the pan-Hellenic humnos of the Olympian Muses. The Hesiodic Theogony ultimately defines itself as one single continuous gigantic humnos. ${ }^{37}$

Similarly in the Homeric Hymn to Apollo, the dramatized encounter of the aoidos 'singer' with the local Delian Maidens leads to the transformation of their local humnos 'hymn' to

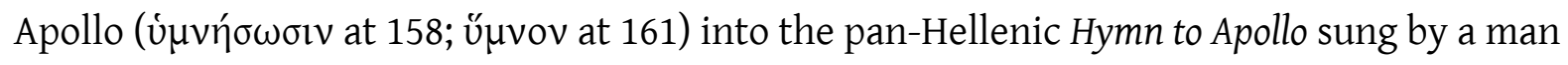
described as $\{285 \mid 286\}$ 'the most pleasing of all singers [aoidoi]' (169). This aoidos 'singer' is further described, in the words of the Delian Maidens, as a blind man whose home is on the island of Chios (172). His aoidai 'songs', as the words of the Delian Maidens prophesy, will be supreme, performed throughout the cities of humankind (173-175).

This aoidos 'singer' of the Homeric Hymn to Apollo, like Hesiod, is a master of poetic kleos 'fame': he speaks about the kleos of the hymn performed by the Delian Maidens (Hymn to Apollo 156), and he promises that he will spread that kleos (174) throughout all the cities he visits (173-175). The pan-Hellenization of the Delian Maidens, like the pan-Hellenization of the Heliconian Muses, is a matter of reciprocated kleos. The description of the blind aoidos from Chios who will spread the kleos of the Delian Maidens throughout the cities of humankind (172-175) starts with a quotation spoken by the Delian Maidens (172-173) in response to an

'Delian Maidens', if the categories of choral groupings included women as well as unmarried 'maidens'; in that case, it may be preferable to use a more inclusive translation, 'Deliades'.

${ }^{35}$ Nagy 1990b:58.

${ }^{36}$ Nagy 1996b:124-128.

${ }^{37}$ Nagy 2008a:2\$15. 
unnamed wanderer, 'someone' (tis) who arrives in Delos and asks the Delian Maidens this question: who is the best aoidos of all? (169-170). When the Delian Maidens 'respond' (ن́rokpív $\sigma \sigma \theta \alpha 1$ 171) to the question of this unnamed wanderer, of this 'someone', it is the quotation of their performed words that reciprocates the kleos: the quoted response of the Maidens (173-175) identifies the best aoidos with the aoidos who quotes their response about him, who will confer kleos on the Delian Maidens as he wanders throughout the cities of humankind.

In the riddling language of the Homeric Hymn to Apollo, the unnamed wanderer to Delos, this 'someone' whose question to the Delian Maidens is quoted in the Hymn (169-170), can be the same persona as the unnamed aoidos 'singer' of the Hymn who quotes the response of the Delian Maidens (172-173), who is the same persona as the unnamed aoidos who will now wander from Delos to all the cities of humankind, a bearer of the poetic kleos 'fame' that is reciprocated between him and the Maidens (174-175). This composite unnamed persona is the figure of Homer himself.

The identity of Homer in the Homeric Hymn to Apollo is expressed by way of riddling and even mantic speech. The description of the 'someone' who has reached Delos after arduous wandering (167-168) anticipates the response (174-175) to the question 'who?' (169-170). That response (174-175) pictures the master singer who wanders throughout the cities of humankind. But this master singer is not explicitly named as Homer. Instead, his identity is implicit in the riddle posed by the question: he is the answer to the question 'who?' - but he is also the 'someone' that asks the question 'who?' The response of the Delian Maidens is Homer's own $\{286 \mid 287\}$ response, since their response is quoted by him. The singer who leaves Delos with an answer loops back to the singer who arrives at Delos with a question. ${ }^{38}$ This looping effect has its own significance: each time this wandering singer arrives at Delos, he becomes a regeneration of Homer as he sings in Delos. Each time the wandering figure of Homer is pictured as singing in Delos, the Delian Maidens authorize him all over again. The eternal return of Homer is made possible by the notionally eternal recycling of his songs.

In sum, the Delian Maidens are figured as local Muses whose interaction with Homer on the island of Delos transforms him into a poet of pan-Hellenic stature - while transforming them into goddesses of commensurate pan-Hellenic stature. ${ }^{39}$ After his encounter with the Delian Maidens, the poet of the Homeric Hymn to Apollo becomes a pan-Hellenic celebrity: he is pictured as wandering from city to city throughout the Hellenic world (174-176). As a pan-

\footnotetext{
${ }^{38}$ In the Homeric Hymn to Apollo (168), according to the version quoted by Thucydides (3.104.5), the wanderer who arrives at Delos is described as allos - seemingly some person 'other' than the speaker. Even in terms of this variant, my formulation holds: this seemingly 'other' person becomes the same person as the speaker once the response of the Delian Maidens to that 'other' person is actually quoted by the speaker.

${ }^{39}$ Nagy 2006:317-322.
} 
Hellenic wanderer, Homer is said to be spreading the poetic kleos 'fame' of the Delian Maidens (174), and this fame is pictured as a reciprocation of the fame of his own poetry, which is universalized and absolutized as the best poetry that exists and will exist for all time to come (173).

\section{The names of Hesiod and Homer}

By now we have seen how the identity of Homer is defined by the local Muses of Delos just as the identity of Hesiod is defined by the local Muses of Helicon. But there is more to it. Even the names of Hesiod and Homer are defined by the Muses. These names, as we will now see, tell their own story.

The name of Hesiod is announced in the Hesiodic Theogony (22): it is Hēsiodos ('Hoíođoc). I interpret the etymology of this name as *hesi-wodos, meaning 'he who emits the voice'. The first part of this compound formation *hēsi-wodos comes from the root of the verb hienai (ićvol) 'emit', while the second part comes from the root of the noun aude ( $\alpha \dot{u} \delta \eta \dot{n})\{287 \mid 288\}$ 'voice'. ${ }^{40}$ And the Muses literally 'breathe' (pneîn) into him an audē 'voice' that makes him a poet (31

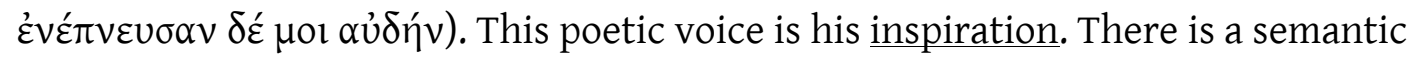
correspondence between this etymology of *hēsi-wodos meaning 'he who emits the voice' and the description of the singing Muses as ö $\sigma \sigma \alpha v$ i $\varepsilon \mathbf{i} \sigma \alpha 1$ 'emitting the voice' (Theogony 10, 43, 65, 67), which applies to these goddesses in descriptions of their singing and dancing $(7-8,63)$.

An analogous point can be made about the etymology of the poetic name of Homer, Homerros ("Ounpos, Thucydides 3.104.4). The morphology of this name can be explained as a compound formation *hom-āros meaning 'he who fits [the song] together', composed of the

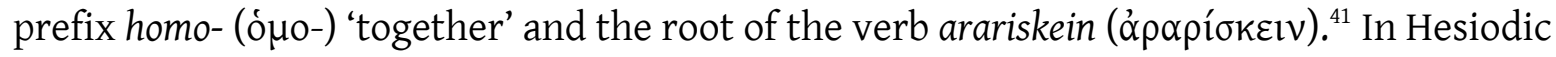
poetry, we find a semantic correspondence between this etymology and descriptions of the Muses in the act of performing their song: in these performative contexts, the goddesses are described as $\varphi \omega v \tilde{n}$ o $\mu \eta \rho \varepsilon \tilde{v} \sigma \alpha 1$ 'fitting things together [homereuein] with their sound' (Theogony 39) and ó $\rho \tau \imath \varepsilon ́ \pi \varepsilon l \alpha l ~ ' h a v i n g$ words [epea] fitted [arariskein] together' (Theogony 29). ${ }^{42}$

As we see even from their names, then, both Homer and Hesiod are linked with the generic function of the Muses as goddesses of poetry. "Homer" and "Hesiod" are not preexisting names of persons who happened to become poets. Rather, they are predestined names for poets in their function of practicing the poetry of the Muses. Such is the poetry attributed to Homer and Hesiod, and their names tell about this poetry.

An analogous formulation applies to whatever "Hesiod" says about Hesiod in Hesiodic poetry and whatever "Homer" says about Homer in Homeric poetry. In both cases, the basic

\footnotetext{
${ }^{40}$ Nagy 1990b:47n32.

${ }^{41}$ Nagy 1979:296-300 (17§§9-13).

${ }^{42}$ Nagy 2006:321-322; also 1990a:372-373 (12\$66).
} 
reality of what these poets say about themselves is not some kind of reportage about their life and times. Rather, the basic reality is the poetry itself, which was understood to be the poetry of the Muses. That is why the names of both Homer and Hesiod are based on epithets describing the poetic powers of the Muses. And these poetic powers are pan-Hellenic in scope. $\{288 \mid 289\}$

\section{The symmetrical pan-Hellenization of Hesiod and Homer}

The pan-Hellenization of Hesiod and Homer is expressed, as we have seen so far, in terms of their interactions with their Muses. But how exactly are these two poets panHellenic? In the case of Hesiod, as we have already seen, his pan-Hellenization is expressed through the relocalization of his Muses from Helicon to Olympus. In the case of Homer, we have seen in the Iliad that his Muses are likewise localized at Olympus. So Olympus indicates a symmetry in the pan-Hellenization of Hesiod and Homer.

There are also other indications of such symmetry, including the fact that the compound noun pan-Hellēnes 'all Greeks' is attested in Homeric poetry (Iliad II 530) as well as in Hesiodic poetry (Works and Days 528). But the most important of these indications is the dialectal texture of the poetic language common to Hesiodic and Homeric poetry. That dialectal texture is predominantly Ionic and residually Aeolic. ${ }^{43}$

In the case of Hesiod, the predominance of the Ionic dialect in the language of his poetry comes as a surprise. After all, as we know from the explicit testimony of the "Life of Hesiod" stories that are interior to Hesiodic poetry, Hesiod is from Boeotia. And, as we know from the surviving linguistic evidence, the dialectal heritage of all Boeotia was predominantly Aeolic and not even residually Ionic. Still, the dialectal texture of Hesiodic poetry is predominantly Ionic - even more distinctly Ionic than the dialectal texture of Homeric poetry. ${ }^{44}$

And the pervasive Ionic heritage of Hesiodic poetry extends from form to content. For example, the only month mentioned in the Hesiodic Works and Days is Lènaiōn (504), which is an exclusively Ionic form. ${ }^{45}$ Moreover, the description of the north wind as it blows over the sea from Thrace in the verses immediately following the mention of Lēnaiōn (Works and Days 505508) reflects a vantage point that cannot be matched with any point located in the region of Boeotia on the Helladic mainland. Rather, the Hesiodic vantage point here matches the Homeric vantage point of the Ionic-speaking populations of Asia Minor who inhabited the regions near the Hellespont and the plain of Troy, which is the poetic setting of the Homeric

\footnotetext{
${ }^{43}$ Nagy 2008b:58-70.

${ }^{44}$ Nagy 1990b:61-63.

${ }^{45}$ Nagy 1990b:63.
} 
Iliad. ${ }^{46}$ It is as if Hesiod were standing where Achilles once $\{289 \mid 290\}$ stood as he looked out over the vast Hellespont and watched the winds swell the waves of its stormy waters (as at Iliad XXIII 229-230).

In the case of Homer, by contrast, the predominance of the Ionic dialect in the language of his poetry comes as no surprise. In the "Life of Homer" myths, Homer is consistently associated with the Ionic cities of Asia Minor and its major outlying islands. The most prominent example is the myth embedded in the Homeric Hymn to Apollo, where the homeland of Homer is said to be the island of Chios (172). From the surviving linguistic evidence, we know that the dialectal heritage of Chios was predominantly Ionic and residually Aeolic. ${ }^{47}$

There was also a wide variety of other "Life of Homer" myths localized in places other than Chios, and in each case the place where the myth originated was supposed to be linked with the life and times of the poet. In most cases, these places were Ionic: that is, they were cities in the region of Asia Minor known as Ionia.

In one exceptional case, however, a city claiming to be closely linked with Homer was Aeolic: that city was Cyme, located in the region of Asia Minor known as Aeolis (Ephorus of Cyme, FGH 70 F 163, by way of Strabo 13.1.39 (600). It was in Cyme, according to the local tradition reported in one of the "Life of Homer" narratives, that Homer was conceived (Homeric Vita 1.3-17 ed. Allen). ${ }^{48}$

In another exceptional case, a city claiming to be closely linked with Homer was known to have been Aeolic in earlier times and Ionic only in later times: that city was Smyrna. Smyrna had already turned Ionian by $\{290 \mid 291\}$ the time of the twenty-third Olympiad (Pausanias

\footnotetext{
${ }^{46}$ West 1978:27.

${ }^{47}$ Bechtel 1924:32.

${ }^{48}$ References to "Life of Homer" narratives will follow the edition of Allen 1912 (in the Thesaurus Linguae Graecae, the numbering of pages and lines follows what is found in this edition). Here are the relevant texts:

\begin{tabular}{|c|c|c|}
\hline Vita 1 & = Vita Herodotea & pp. 19-218 \\
\hline Vita 2 & $=$ Contest of Homer and Hesiod & pp. $225-238$ \\
\hline Vita 3a & $=$ Plutarchean Vita & pp. $238-244$ \\
\hline Vita $3 b$ & $=$ Plutarchean Vita & pp. $244-245$ \\
\hline Vita 4 & $=$ Vita quarta & pp. $245-246$ \\
\hline Vita 5 & $=$ Vita quinta & pp. $247-250$ \\
\hline Vita 6 & $=$ Vita sexta (the "Roman Life") & pp. $250-253$ \\
\hline Vita 7 & $=$ Vita septima, by way of Eustathius & pp. $253-254$ \\
\hline Vita 8 & $=$ Vita by way of Tzetzes & pp. $254-255$ \\
\hline Vita 9 & $=$ Vita by way of Eustathius (on Iliad IV 17) & p. 255 \\
\hline Vita 10 & $=$ Vita by way of the Suda & pp. $256-268$ \\
\hline Vita 11 & $=$ Vita by way of Proclus & pp. 99-102 \\
\hline
\end{tabular}

There is a new edition of Vitae 1 and 2 by Colbeaux 2005.
} 
5.8.7), that is, by the end of the eighth century. I quote this apt formulation: "[Smyrna], lying more than ten miles south of the [river] Hermus, and having Phocaea on the coast between it and Cyme, belonged naturally to the Ionian sphere." ${ }^{49}$ It was in Smyrna, according to the local tradition reported in the same "Life of Homer" narrative I cited a moment ago, that Homer was born (Homeric Vita 1.17-31).

As we know from the surviving linguistic evidence, the dialectal heritage of Smyrna was Ionic and only residually Aeolic; by contrast, the dialectal heritage of Cyme remained Aeolic, though heavily influenced by Ionic. Correspondingly, what we have found so far in the "Life of Homer" stories is a complex of myths that function as an aetiology for the Ionic and residually Aeolic heritage of Homeric poetry..$^{50}$ And this cultural heritage is aetiologized by way of representing Homer as originating directly - by way of his birth - from the city of Smyrna, which had an Ionic and residually Aeolic heritage, and indirectly - by way of his conception from the city of Cyme, which had an Aeolic heritage that was strongly influenced by Ionic. ${ }^{51}$

In the "Life of Hesiod" stories, what we find is a comparable aetiology for the Ionic and residually Aeolic heritage of Hesiodic poetry. In this case, however, the aetiology takes the form of a myth that is actually embedded within Hesiodic poetry. According to this myth, which we find in the Hesiodic Works and Days (633-640), Hesiod originates indirectly - by way of his father - from the city of Cyme, which as we have seen had an Aeolic heritage strongly influenced by Ionic. That is, Hesiod's father originates directly from Cyme: according to the Hesiodic Works and Days, he is said to have migrated from that city on the Asiatic mainland (636) to the town of Ascra on the Helladic mainland (639-640).

The path taken by Hesiod's father, in migrating from Aeolic Cyme on the Asiatic Mainland to Aeolic Ascra on the Helladic Mainland, signals the utter collapse of this man's mobile Asiatic past and a total validation of the stationary Helladic present represented by Hesiodic poetry. In the Works and Days, this stationary Helladic present is correlated with an ostentatious reference to Hesiod's reluctance to navigate or to travel at $\{291 \mid 292\}$ all: the poetry highlights the idea of Hesiod's hesitancy in crossing the waters of even the narrowest of straits - at Aulis in Boeotia - to compete in the funeral games of Amphidamas at Chalkis in Euboea (Works and Days 646-663). ${ }^{52}$

And this Hesiodic reference to Aulis is ostentatiously Homeric in theme, conjuring the themes of the Homeric Iliad by referring to the launching point of the Trojan War. Thus this

\footnotetext{
${ }^{49}$ How and Wells 1928 I 124.

${ }^{50}$ By aetiology, I mean a myth that motivates an institutional reality: see Nagy 1979:279 (16\$2n2).

${ }^{51}$ Nagy 2009:2\$15.

${ }^{52}$ On the poetic theme of Hesiod's reluctance to navigate, see Rosen 1990 and Martin 1992.
} 
fleeting reference to Aulis in the Hesiodic Works and Days is in and of itself a point of contrast between Hesiodic and Homeric poetry. ${ }^{53}$

The path taken by Hesiod's father is not only a migration from the Asiatic Mainland to the Helladic mainland. It is in effect a reverse migration. ${ }^{54}$ That is because this path represents a reverse of the myth of the Ionian Migration: in terms of that myth, the stationary and even static Helladic past is relocated in the mobile and dynamic Asiatic present of Ionia in Asia Minor, and the Ionian mother city is imagined as Athens on the Helladic mainland. ${ }^{55}$

In terms of this myth of the Ionian Migration, one of the most important daughter cities of Athens was Smyrna, situated on the Asiatic mainland. According to this myth, Homer was born in Smyrna at the time of the Ionian Migration, but he was conceived on the Ionic island of Ios (Aristotle F 76 ed. Rose, via Homeric Vitae 3a.25-26, 3b.10, and 6.13-14). In terms of this version of the myth, Smyrna was an Ionic city. To be contrasted is a pre-Ionic version according to which Homer was born in Smyrna (Homeric Vita 1.17-31) but conceived in the Aeolic city of Cyme (Vita 1.3-17). In terms of this version of the myth, Smyrna was once an Aeolic city, like Cyme.

The linking of Athens as a metropolis or mother city with Smyrna as a daughter city is part of the myth of the Peisistratean Recension. This myth involves the historical figure Peisistratos, founder of a dynasty of tyrants known as the Peisistratidai, who ruled Athens in the sixth century BCE. According to the myth, the shaping of which can be traced back to the historical era of the Peisistratidai themselves, the tyrant Peisistratos of Athens reassembled in Athens the poems of Homer, which had been scattered throughout the Ionian cities of Asia Minor. ${ }^{56}$ The $\{292 \mid 293\}$ simplest formulation of this myth can be found in one of the "Life of Homer" stories:

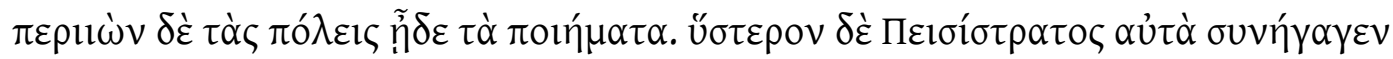
[Homer], as he went wandering around [perierkhesthai] the cities, was singing [äidein] his poetic creations [poiēmata]; later, Peisistratos collected them.

Homeric Vita $4.8-10$

This Homeric Vita goes on to add a most important detail that links Athens as a metropolis or mother city with Smyrna as a daughter city. It quotes an epigram attributed to Peisistratos himself. In this epigram, as quoted by the Vita, the tyrant claims that he personally

\footnotetext{
${ }^{53}$ Again, Rosen 1990 and Martin 1992; also Clay 2003:180-189 (who does not mention Martin's article).

${ }^{54}$ Nagy 1990b:73-74.

${ }^{55}$ Nagy 2009:E§49.

${ }^{56}$ Nagy 2009:E§§11-47.
} 
reintegrated the disintegrated corpus of Homeric poetry as once performed by Homer throughout the cities of Asia Minor. And, in this context, the poetry of the epigram makes a reference to Smyrna as not only the daughter city of Athens but also the birthplace of Homer. Here are the verses of the epigram, as spoken by the persona of the tyrant himself:

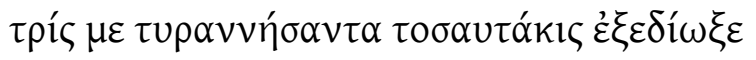

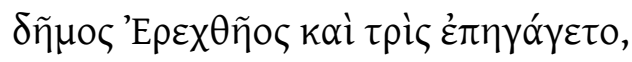

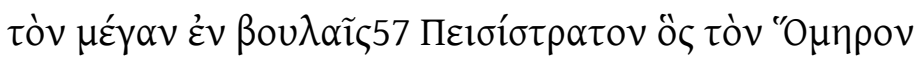

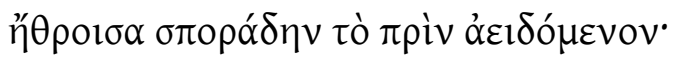

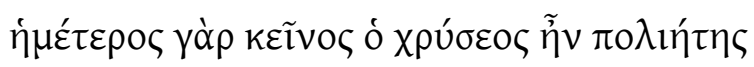

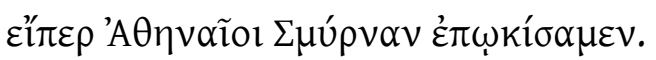

Three times was I tyrant [of Athens], and three times was I expelled

by the people of Erekhtheus [= the Athenians]. Three times did they bring me in [as tyrant], me, Peisistratos, great in counsel. I was the one who took Homer and put him all together. Before that, he used to be sung in a scattered state [sporadenn]. You see, he was our golden citizen [politēs], if it is true that we the Athenians settled [= make an apoikia of] Smyrna.

Homeric Vita 4.11-16

(Also attested in Homeric Vita 5.29-34; also in the Greek Anthology, 11.442.)

This epigram, it is important to add, was reputedly inscribed on the base of a statue of Peisistratos that was publicly displayed in Athens during the era of the Peisistratidai themselves (Homeric Vita 5.26-27).

As we learn from the complex of myths reflected in the wording of this epigram, the story of the Ionian Migration links two mythologized \{293|294\} events: (1) the birth of Homer in Ionic Smyrna and (2) the settlement of this Asiatic city by the Helladic city of Ionic Athens. By contrast, the story of the reverse migration of Hesiod's father that we find embedded in the Works and Days (633-640) links two corresponding mythologized events: (1) the birth of Hesiod in Aeolic Ascra and (2) his father's abandonment of the Asiatic city of Aeolic Cyme. What we saw in the case of the Hesiodic reference to Aulis in the Works and Days (646-663) is analogous to what we see in this case: the Hesiodic reference to Cyme, just like the reference to Aulis, highlights a point of contrast between Hesiodic and Homeric poetry. ${ }^{58}$ In this case, Hesiod's localization in the stationary and even static setting of the Helladic Mainland is being

\footnotetext{
${ }^{57}$ The version given in the Greek Anthology shows a variant at this point: $\beta$ ou $\lambda \tilde{\eta}$.

${ }^{58}$ In this context, I note that Antidoros of Cyme, who flourished sometime around the late fourth century BCE and who was reputedly the first person to call himself a grammatikos, published a disquisition of Homer and Hesiod (scholia for Dionysius Thrax 44.6 ed. Hilgard).
} 
contrasted with Homer's localization in the mobile and dynamic setting of the Asiatic Mainland.

When and where did such points of contrast develop between Hesiodic and Homeric poetry? The answer has to do with an era in the city of Athens when performances of Hesiodic and Homeric poetry could in fact coexist, side by side. The sixth century BCE was such an era. It was the time when the city of Athens was under the political and cultural control of the Peisistratidai.

In the sixth century $\mathrm{BCE}$, during the preclassical era of the Peisistratidai, Homer was understood to be the poet of not only the Iliad and Odyssey but also of other epics collectively known as the epic Cycle. And the epic poetry of this "preclassical" Homer coexisted with epic poetry attributed to other poets, especially to Hesiod. All this poetry was performed, on a seasonally recurring basis, at a major festival of Athens, the Panathenaia. ${ }^{59}$

Part of the Hesiodic repertoire at the Panathenia was the Catalogue of Women, or the Ehoiai. This epic narrative, which was linked directly to the Hesiodic Theogony, is evidently Athenian in provenience. That is, I agree with the argument that the Hesiodic Catalogue was composed in Athens sometime between 580 and $520 \mathrm{BCE}$ and that, "if the addition of [Theogony] 965-1020 was contemporary, the range may perhaps be narrowed to [around] 540-520 [BCE]." The broader and the narrower time frames, (1) 580-520 and (2) 540-520, are based on dating criteria linked respectively to (1) the contents of the Catalogue and (2) the contents of \{294|295\} verses 965-1024 of the Theogony. In terms of these criteria, the Hesiodic Catalogue was composed in Athens as a "text" to be added to the "text" of the Theogony.

A qualification is needed here: the overall "text" of Hesiod resulted from the reception of living oral traditions. And these traditions, as we saw earlier, cannot be viewed exclusively on a synchronic level, as if they resulted in individualized poetic compositions. That is because the actual process of composition was a matter of ongoing recomposition-in-performance. And such a process, as we also saw earlier, needs to be viewed diachronically as well as synchronically.

The beginning of the Catalogue, Hesiod F 1, is a functioning continuation of the narrative that leaves off at verse 1020 of the Theogony, while verses 1019-1020 of the Theogony are a functioning transition into the narrative that begins with the Catalogue. ${ }^{61}$ This is not to say, however, that "our poet [that is, the poet of the Catalogue] rewrote [sic] the end of Hesiod's Theogony in his own style." ${ }^{162}$ I would say rather that the continuity of narration in the

\footnotetext{
${ }^{59}$ Nagy 2009:1§§168-179.

${ }^{60}$ West 1985:136.

${ }^{61}$ West 1985:126.

${ }^{62}$ West 1985:167.
} 
transition from Theogony to Catalogue is an aspect of the same oral traditions that resulted in the texts that we know as the Theogony and Catalogue. ${ }^{63}$

Seen in this light, the composition of Hesiodic poetry is an ongoing process, extending into the ongoing reception of that poetry in Athens during the sixth century BCE.

The coexistence of Homeric and Hesiodic poetry in Athens during the era of the Peisistratidai in the sixth century BCE helps explain a strikingly close parallelism in the way these two distinct sets of poetry systematize the twelve Olympian gods as an elite subset of all the other gods. Such a systematization is not only a matter of poetics. It is also a matter of politics. ${ }^{64}$ More specifically, the poetics of the system of twelve Olympian $\{295 \mid 296\}$ gods as shared by Homeric and Hesiodic poetry derives from the politics of Athens in the era of the Peisistratidai. The cultural reality of the Olympian gods, canonically twelve in number, was grounded in the political reality of the Altar of the Twelve Gods in the Agora of Athens (Herodotus 2.7.1; IG II 2640$){ }^{65}$ Built in the era of the Peisistratidai, this Altar was the notional center of all Attica, that is, of the entire region controlled by the city of Athens, and the herms that had been set up in the various demes of Attica by Hipparkhos, son of Peisistratos, functioned as points of reference for measuring the distances between these demes and their common centerpoint as represented by the city of Athens. ${ }^{66}$

In this context, it is relevant to add that the Peisistratidai were engaged in an aggressive political campaign to appropriate and incorporate the traditions of Boeotia into their pan-Hellenic cultural programs throughout Attica, and a sure sign is the highlighting of Boeotian traditions in Homeric poetry: a striking example is the Homeric Catalogue of Women in the Odyssey (xi 225-330). ${ }^{67}$ Just as the Hesiodic Catalogue of Women shows an abundance of Attic features, as we noted earlier, so also the Homeric Catalogue of Women shows an abundance of Boeotian features. And the point is, such exchanges of Attic and Boeotian features are typical of Homeric and Hesiodic poetry in the era of the Peisistratidai.

\footnotetext{
${ }^{63}$ In terms of oral traditions, the narrative of the Hesiodic Theogony could also function as a preliminary to the Homeric Iliad: such a potential continuity of narration has been demonstrated by Muellner 1996:94-96. In the era of the Peisistratidai, I would add, an earlier form of the Theogony could have been performed as a preliminary to an earlier form of the Iliad.

${ }^{64}$ Nagy 1990b:48-49: "The Olympus of Hesiodic and Homeric poetry is a pan-Hellenic construct that elevates the gods beyond their local attributes.... The evolution of most major gods from most major cities into the integrated family at Olympus amounts to a synthesis that is not just artistic but political in nature, comparable with the evolution of the pan-Hellenic games known as the Olympics." Quoted by Clay 1989:9-10. Hence the title of her book: The Politics of Olympus.

${ }^{65}$ Larson 2000:213-214.

${ }^{66}$ Larson 2000:213.

${ }^{67}$ Larson 2000, especially pp. 204-205.
} 
The coexistence of Homeric and Hesiodic poetry in the sixth century BCE, it needs to be added, became obsolete in the fifth. By the time of the fifth century, only the Iliad and Odyssey were performed at the Panathenaia, and only these two epics were attributed to Homer. ${ }^{68}$

There is still a trace of the old coexistence, however, in a remark made by Herodotus about the symmetry of Homer and Hesiod as a pair of culture heroes who systematized panHellenic thinking about the gods:

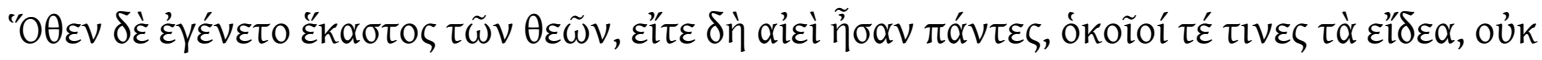

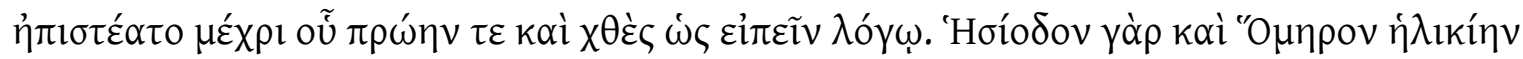

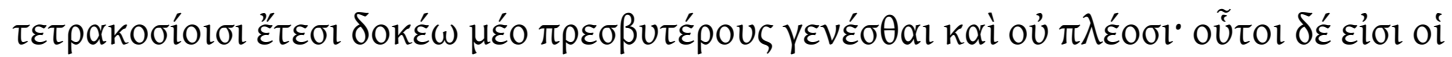

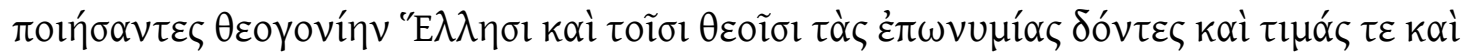

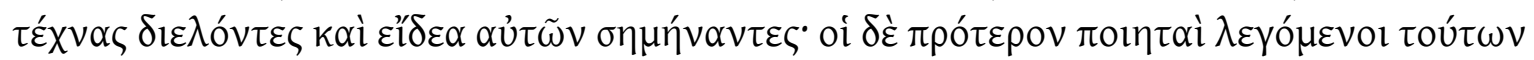

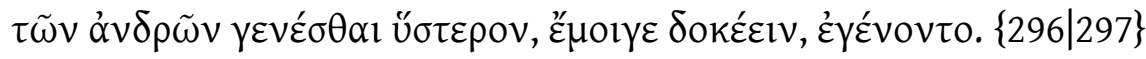

But it was just the day before yesterday, so to speak, that they [= the Hellenes] came to understand where each of the gods originated from, whether they all existed always, and what they were like in their visible forms [eidos plural]. For Hesiod and Homer, I think, lived not more than four hundred years ago. These are the men who composed [poiein] a theogony [theogonia] for the Hellenes, who gave epithets to the gods, who distinguished their various spheres of influence [timai] and spheres of activity [tekhnai], and who indicated [semmainein] their [= the gods'] visible forms [eidos plural]. And I think that those poets who are said to have come before these men really came after them.

Herodotus 2.53.1-3

By the time we reach the era of Plato in the fourth century BCE, we find that the symmetry of Homer and Hesiod is well known again, at least in antiquarian intellectual circles. For example, Plato's Socrates imagines Homer and Hesiod in the act of 'performing in the manner of rhapsodes' (rhapsōidein) as they 'go wandering around' (perierkhesthai) from city to city (Plato

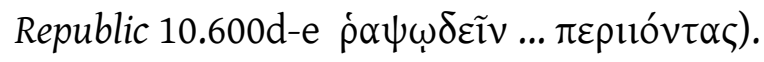

\section{The Contest of Homer and Hesiod}

The stylized reference by Plato's Socrates to Homer and Hesiod as rhapsodic performers evokes the image of itinerant professional rhapsoidoi 'rhapsodes' who compete with each other at urban festivals. A prime example of such rhapsodic competitions is the tradition of performing Homeric and other epic poetry at the festival of the Panathenaia in the city of Athens. And these rhapsodic performances were not only competitive: they were also collaborative. At this festival, already in the era of the Peisistratidai, competing rhapsodes were required to take turns in performing sequentially the Homeric Iliad and Odyssey ("Plato"

\footnotetext{
${ }^{68}$ Nagy 2009:1§§35-54.
} 
Hipparkhos 228b-c). And there must have been some degree of collaboration in the act of competition, since the rhapsodes competing at the Panathenaia would be expected to complement each other in performing different parts of a \{297|298\}notionally integral composition like, say, the Homeric Iliad.$^{69}$ I posit an analogous pattern of competitive collaboration in the rhapsodic performance of Hesiodic poetry in the era of the Peisistratidai: in this case as well, rhapsodes competing at the Panathenaia would be expected to complement each other in performing different parts of a notionally integral composition like, say, the Theogony in conjunction with the Catalogue of Women.

Even more than that, there must have existed a tradition of rhapsodic competition involving rival performances of Hesiodic and Homeric poetry. Traces of such a tradition survive in myths about a primordial contest between Homer and Hesiod. The most prominent example of such myths is attested in an anonymous work known as the Contest of Homer and Hesiod (= Homeric Vita 2 ed. Allen; hereafter cited simply as Vita 2).$^{70}$ According to the story as preserved in this work, Homer is defeated by Hesiod in a poetic competition held in the city of Chalkis in Euboea on the occasion of funeral games commemorating the death of a king named Amphidamas, though the narrative attributes the victory of Hesiod to the favoritism of the current king who overrules the favorable reception of Homer over Hesiod by the people attending the competition (Vita 2.62-64). ${ }^{71}$ In the course of this competition, Hesiod tests Homer by challenging him to perform a variety of feats in poetic improvisation (Vita 2.72-204). And the formal characteristics of Hesiod's quoted poetic challenges and Homer's quoted poetic responses are in fact typical of what we find in ancient reportage concerning rhapsodic competitions that actually took place in the historical period extending from the sixth into the fourth century BCE. ${ }^{72}$

In the text of the Contest, Homer is explicitly pictured as a rhapsode who wanders from

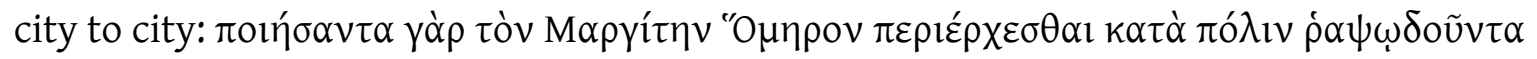
'having made [poieîn] the [comic poem] Margites [in the city of Colophon in Asia Minor], Homer

\footnotetext{
${ }^{69}$ Nagy 2002:36-69. For a comparative perspective on the concept of competition-incollaboration, see Nagy 1996a:18.

${ }^{70}$ Unfortunately, this text is not included among the Hesiodic testimonia collected in the Loeb Classical Library volume edited by Most (2006:154-281), who refers only in passing (pp. 163, 183 ) to the version of the text as included in the Loeb Classical Library volume containing Homeric testimonia, edited by West 2003:318-353. Most relevant to the Contest is a detail in Michigan Papyrus 2754, originally published in Winter 1925, concerning the universalized reception of Homer. See Colbeaux 2005.77.

${ }^{71}$ In the text of the Contest of Homer and Hesiod, there are two mutually contradictory versions about the venue. At one point, the setting for the contest of Homer and Hesiod is said to be Aulis, described as belonging to Boeotia (2.54-55). At a later point, however, the setting is said to be Chalkis in Euboea (2.68).

${ }^{72}$ Collins 2004:177-178, 185.
} 
went wandering around [perierkhesthai] from city to city, performing in the manner of rhapsodes [rhapsoiideîn]' (2.55-56). After he is defeated by Hesiod, Homer is said to continue his life as a wandering rhapsode, and the wording echoes the earlier wording we saw just a

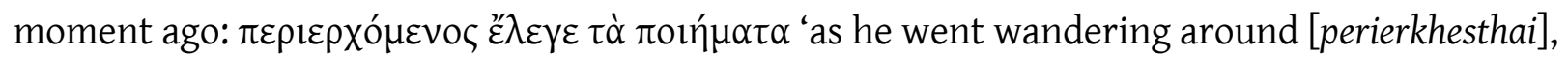
he was telling his poetic creations [poiēmata]' (2.255).

The text of the Contest as we have it dates back to the mid second century CE, but it derives ultimately, as Friedrich Nietzsche was the first $\{298 \mid 299\}$ to argue in modern times, from the work of Alcidamas of Athens, a contemporary of Plato (both flourished in the first half of the fourth century BCE). ${ }^{73}$ Here I find it relevant to recall the wording of Plato himself: as we saw earlier, Plato's Socrates pictures both Homer and Hesiod in the act of 'performing in the manner of rhapsodes' (rhapsoiidein) as they 'go wandering around' (perierkhesthai) from city

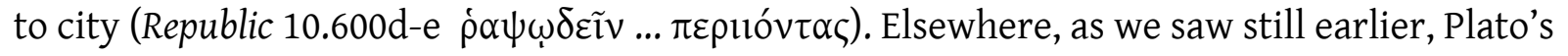
Socrates pictures Homer and Hesiod in the act of speaking through the rhapsodic medium of his own day when he says that 'these two poets composed false stories which they told and still

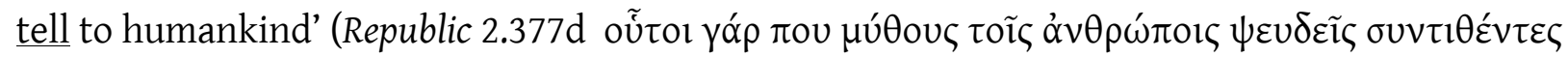

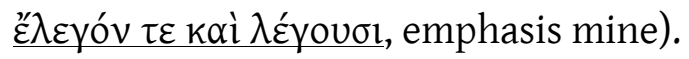

It has been argued that the story of the Contest of Homer and Hesiod as mediated by Alcidamas was his own invention, based on a passing reference in Hesiodic poetry to a poetic contest that Hesiod had won in Chalkis:

The story of the contest with Hesiod was based on Hesiod's own mention of a victory that he won in a poetic competition at the funeral games for Amphidamas in Chalcis (Works and Days 650-659). It is ignored in the other lives [of Homer] (except that Proclus [Homeric Vita 11.8-12] dismisses it), and it may have been Alcidamas' invention. ${ }^{74}$

But the argument that this story was invented by Alcidamas in the fourth century BCE is untenable. Even in terms of this argument, it has to be admitted that the verses quoted in the text of the Contest as the verses of Homer and Hesiod themselves "were already current in the fifth century." 75 And there is ample evidence to show that the myths embedded in the text of the Contest must be far earlier than even the fifth century BCE. ${ }^{76}$

A major part of this evidence has to do with a pattern of symmetry that persists between the divergent stories of Hesiod and Homer after the convergent story about their contest comes to an end and the two poets go off on their separate ways. The experiences that

\footnotetext{
${ }^{73}$ Nietzsche 1870; for background: West 2003:298.

${ }^{74}$ West 2003:299.

${ }^{75}$ West 2003:299.

${ }^{76}$ Nagy 2009:1§§135-136, 139, 141-142, 151, 156, 171; 2\$§24-27, 30, 351; E§§23, 25-26, 44, 53-56, $58-62,94,110$.
} 
still await Homer and Hesiod in the text of Contest reveal remarkable parallelisms. Here is an example: $\{299 \mid 300\}$

After he defeats Homer in the contest, Hesiod sails to Delphi, where he makes an offering to the god Apollo as a sign of his gratitude for winning a bronze tripod as a prize for his victory (Vita 2.215-217). It is implied that the offering made by Hesiod to the god may be the tripod itself; earlier in the narrative, he is said to have dedicated the tripod to the Heliconian Muses, composing an epigram to be inscribed on it (Vita 2.210-214). ${ }^{77}$

After he is defeated by Hesiod in the contest, Homer experiences a series of new adventures (Vita 2.254-271), climaxing in his own journey to Delphi, where he makes an offering to the god Apollo as a sign of his gratitude for winning a silver phiale as a prize for composing an epigram to commemorate the death of Midas (Vita 2.271-276). ${ }^{78}$ It is made explicit that the offering made by Homer to the god is the phiale itself, which he dedicates directly to Apollo, composing an epigram to be inscribed on it (Vita 2.271-272).

The symmetry of these mythological details about Homer and Hesiod can be supplemented with further details we find in texts that are independent of the text of the Contest of Homer and Hesiod. For example, the detail about the presence of Hesiod in Delphi can be supplemented with details provided by Pausanias (10.7.3), who says that Hesiod was expelled from a poetic contest at Delphi because he was unable to play the lyre - evidently because he was a rhapsode, and rhapsodes conventionally perform without instrumental accompaniment in the historical period.

In this case, it is not made explicit whether Hesiod is being envisioned as engaging in another poetic contest with Homer - this time in the context of a festival held in honor of Apollo at Delphi. In another case, however, it is made quite explicit that such a contest is in fact being envisioned - this time in the context of a festival held in honor of Apollo at Delos. Here is the relevant passage, referring to a contest of Homer and Hesiod that took place at Delos:

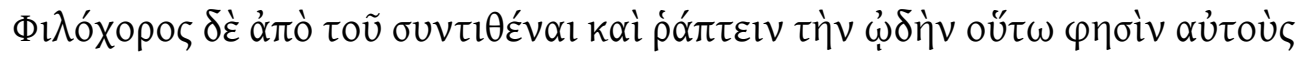

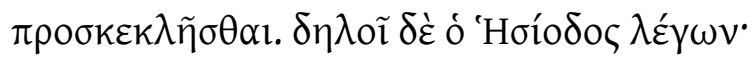

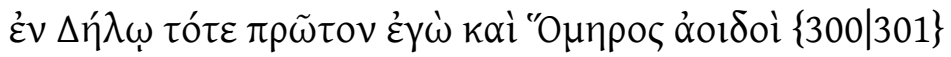

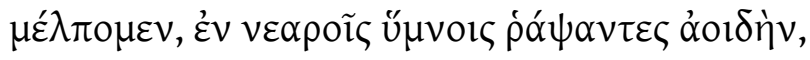

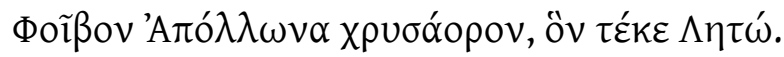

\footnotetext{
${ }^{77}$ We should expect rival versions concerning the whereabouts of the tripod: for example, Pausanias (9.31.3) mentions an ancient tripod belonging to Hesiod that was on display in the Valley of the Muses in the region of Helicon; see also Aulus Gellius Attic Nights 3.11.1-5. On the idea of Hesiodic composition in the form of epigrams, see the next note.

${ }^{78}$ On the idea of Homeric composition in the form of epigrams, see Nagy 2004a:51n20.
} 


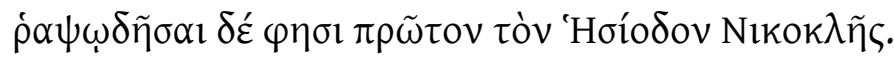

Philochorus [FGH 328 F 212] says that they [= rhapsōidoi] were called that [= rhapsōidoi] on the basis of the idea of composing, that is, stitching together, the song. Proof for this comes from Hesiod, who says [= Hesiod F 357]:

In Delos, back then at the very beginning, I and Homer, singers [aoidoi], sang and danced [melpein],79 stitching together [rhaptein] a song in new humnoi, making Phoebus Apollo the object of our song, the one with the golden weapon, the one born of Leto.

Nicocles [FGH 376 F8] says that Hesiod was the first to perform rhapsodically [rhapsōideîn].

Scholia for Pindar Nemean 2.1d

The combination of mythological details concerning the presence of Homer and Hesiod in Delos as well as in Delphi amounts to an aetiology of the Homeric Hymn to Apollo as we have it, which is part Homeric and part Hesiodic. As Richard Martin has shown, the verses of the Homeric Hymn to Apollo celebrating the god Apollo at Delphi are distinctly Hesiodic in style, whereas the verses celebrating the god Apollo at Delos are distinctly Homeric. ${ }^{80}$ By Hesiodic Martin means the style characteristic of the Theogony and Works and Days; by Homeric he means the style characteristic of the Iliad and Odyssey.

We have already noted that the Delian part of the Homeric Hymn to Apollo narrates the myth of Homer's encounter with the Delian Maidens on the island of Delos. But we have not yet noted that this myth was linked to the Delia, a seasonally recurring festival at Delos. As we will now see, this festival is relevant to the myth about Homer and Hesiod at Delos.

The festival of the Delia, as we know from historical sources including Thucydides (3.104.2-6), was understood to be the shared heritage of all Ionian Greeks - and thus a shared expression of Ionian identity. For this reason, the Peisistratidai of Athens made the political move of seizing control over Delos, thus appropriating the festival of Apollo at Delos, the Delia. ${ }^{81}$ This move, which was part of their overall policy of promoting Athens as the notional metropolis of all Ionians, was matched by another move: the Peisistratidai appropriated not only the festival of the Delia but \{301|302\} also the Homeric Hymn to Apollo as a formal expression of that festival. And, by way of appropriating the Hymn, the Peisistratidai appropriated Homer himself in the act of performing the Hymn. When we see Homer in the act

\footnotetext{
${ }^{79}$ The verb melpesthai and the noun molpe convey the combination of singing and dancing: Nagy 1990a:350-351 (12§29) n62 and n64.

${ }^{80}$ Martin 2000b.

${ }^{81}$ On Delos and the Peisistratidai, see Aloni 1989:43-44.
} 
of interacting with the Delian Maidens in the Homeric Hymn to Apollo, he is in effect being pictured as performing at this festival. ${ }^{82}$

The Peisistratidai appropriated not only Homer but also Hesiod, who is pictured together with Homer in the act of competitively performing a hymn to Apollo in the passage I quoted from Philochorus. And, as we noted earlier, the verses of the Homeric Hymn to Apollo celebrating the god Apollo at Delphi are distinctly Hesiodic in style, just as the verses celebrating the god Apollo at Delos are distinctly Homeric. But Hesiod, unlike Homer, is a recessive figure in the Hymn as we have it. In the end, the Hymn to Apollo survives as a Homeric hymn, not a Hesiodic one. Ultimately, that is because the Peisistratidai never succeeded in seizing control over Delphi and thus could never appropriate the festival of Apollo at Delphi, the Pythia. A modified form of control over Delphi was achieved instead by a rival Athenian family, the Alkmaionidai. The Peisistratidai controlled only Delos, not Delphi, and they could appropriate only the festival of Apollo at Delos, the Delia, but not the festival of Apollo at Delphi, the Pythia.

As a substitute for Delphi, however, the Peisistratidai managed to establish control over Ptōon, a major cult center of Apollo in Boeotia. ${ }^{83}$ This political move by the Peisistratidai was a major part of their aggressive political campaign to appropriate and incorporate the traditions of Boeotia into their own pan-Hellenic cultural programs. And, in this indirect way, Hesiod of Boeotia became a spokesman for the agenda of Apollo at Delphi. Still, in the Homeric Hymn to Apollo, there is no way for Hesiod to compete directly with Homer at Delphi. They can compete with each other, at least indirectly, at Delos instead.

Although neither Homer nor Hesiod is named in the Homeric Hymn to Apollo, at least one of them wins out. And that winner is in this case Homer, not Hesiod. As we saw earlier, Homer's interaction with the Delian Maidens in the Hymn leads to his status as a pan-Hellenic celebrity: once he leaves Delos behind, he will wander from city to city throughout the Hellenic world (174-176), spreading the poetic kleos 'fame' of the Delian Maidens (174), and this fame will be a reciprocation $\{302 \mid 303\}$ of the fame of his own poetry, which is thus universalized (173). And by now we see that this universalization of Homer as a spokesman for all Greeks - and, more significantly, for all Ionian Greeks - stems from his performance at the festival of the Delia in Delos.

Just as Homer's performance at Delos establishes his status as a universalized spokesman for Ionian Greeks in the era of the Peisistratidai, so also Hesiod's performance at Delos makes him a rival spokesman, at least from the standpoint of Athens as the notional metropolis of all Ionians. We have already noted the Ionic texture of Hesiodic poetry, which is

\footnotetext{
${ }^{82}$ Nagy 2009:1§§139-140.

${ }^{83}$ A detailed history of this initiative of the Peisistratidai in Boeotia is provided by Larson 2002.
} 
symmetrical with the Ionic texture of Homeric poetry. Now we see that this symmetry is aetiologized in the myth that tells of a contest of Homer and Hesiod on the island of Delos.

The symmetry of mythological details about Homer and Hesiod can be supplemented with still further details we find in texts that are independent of the text of the Contest of Homer and Hesiod. An example is provided by Plutarch (Banquet of the Seven Sages 10 pp. 153f-154a), who says that the poet Hesiod was put to the test by a poet other than Homer during the contest of Homer and Hesiod at Chalkis; in this version of the myth, there are other poets involved in the contest besides Homer and Hesiod, and one of them is Lesches of Lesbos, who questions Hesiod by way of quoting verses from his own poetry (Lesches Little Iliad F 23 ed. Allen), to which Hesiod responds by way of quoting verses of his own (p. 56.2-3 ed. Wilamowitz). In the version of the myth as we see it in the Contest of Homer and Hesiod, by contrast, the verses that match closely the verses quoted by Lesches are attributed to Hesiod (Vita 2.97-98), whereas the verses that match closely the verses quoted by Hesiod are attributed to Homer (Vita 2.100-101).

The story of a poetic competition between Hesiod and Lesches, as reported by Plutarch, is analogous to the story of a poetic competition between two poets of the epic Cycle, Arctinus of Miletus and Lesches of Lesbos, as reported by Phaenias of Eresos in Lesbos, who flourished in the fourth century BCE (F 33 ed. Wehrli; via Clement Stromateis 1.131.6). And the detail showing Hesiod being tested by a poet of the epic Cycle is a missing piece that supplements what we see in the text of the Contest, where Hesiod is not tested by Homer and where only Homer gets to be tested by Hesiod. In other words, this detail as reported by Plutarch fills out a parallelism that is not fully expressed in the text of the Contest. The parallelism of Homer and Hesiod as symmetrically matched poetic opponents is formalized in that text only at the very end, when the storytelling reaches the final phase of the contest (Vita 2.176-210): "It $\{303 \mid 304\}$ is only when each poet is asked to recite the finest piece of his poetry that their abilities can be weighed against one another." ${ }^{84}$

I have saved for last what may be the most decisive piece of evidence to show that the symmetrical myths about Homer and Hesiod as embedded in the text of the Contest of Homer and Hesiod are not mere inventions made by antiquarians. It has to do with a variant verse reported by the scholia for the Hesiodic Works and Days (657a ed. Pertusi). In this variant, we find Hesiod declaring that his adversary in the poetic contest that he won in Chalkis was Homer himself:

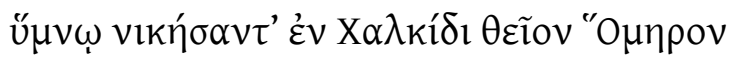
defeating god-like Homer in song, at Chalkis instead of

\footnotetext{
${ }^{84}$ West 2003:200.
} 


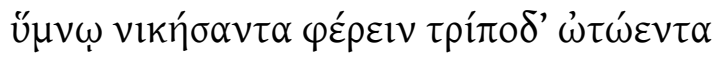

winning in song, (I say that I) carried away (as a prize) a tripod with handles on it.

Hesiodic Works and Days 657

The variant verse mentioning Homer is also attested in the Contest of Homer and Hesiod (Vita 2.213-214 ed. Allen), where it is part of an epigram ascribed to Hesiod, who reputedly composed it in celebration of his victory over Homer.

All this is not to question whether the variant verse as attested in the medieval manuscript tradition of the Works and Days (657) is genuine. This verse mentioning the tripod itself may be just as genuine as the verse mentioning Homer. And each one of these two alternative verses is composed in an epigrammatic style that characterizes the verses that follow (658-659) as also the verse that precedes (656). Though both of these two variant verses may be genuine, the one that directly mentions Homer must have been phased out "in the course of the poem's crystallization into a fixed text." ${ }^{15}$

\section{Hesiod the cult hero}

The symmetrical myths about Homer and Hesiod as embedded in the text of the Contest of Homer and Hesiod provide a wealth of information, as we have seen, about the reception of Homeric and Hesiodic poetry. $\{304 \mid 305\}$ One kind of information has yet to be examined. It has to do with the hero cults of Homer and Hesiod. The information we find in the Contest concerning Homer as cult hero is particularly noteworthy (Vita 2.92-94, 287, 303-308) ${ }^{86}$ In what follows, however, I confine myself to the information in the Contest concerning Hesiod as a cult hero in his own right. ${ }^{87}$

I start with a myth that tells about the murder of Hesiod at the precinct of Zeus Nemeios. There is a celebrated mention of this myth by Thucydides (3.96.1), but its relevance to the hero cult of Hesiod emerges only from later sources, including the text of the Contest of Homer and Hesiod. According to this text (Vita 2.224-240), two men murder Hesiod because he allegedly seduced their sister, and the murderers then sail out to sea and throw his corpse overboard; the corpse is rescued by a school of dolphins and carried by them to a beach at Rhion, where a festival is in progress. In the text of the Contest of Homer and Hesiod, it is at this point that the Mouseion of Alcidamas of Athens is explicitly cited as the source of the narrative (Vita 2.239-240).

This version of the myth, as derived from the Mouseion of Alcidamas, is followed in the text of the Contest by a second version of the myth, derived from a monograph by Eratosthenes

\footnotetext{
${ }^{85}$ Nagy 1990b:78, with further argumentation.

${ }^{86}$ Commentary in Nagy 2009:1§§124-136.

${ }^{87}$ For an overall study of the hero cults of poets, including Hesiod, see Clay 2004.
} 
about Hesiod (Vita 2.240-247). As the retelling of this second version comes to an end, it is reported that the corpse of Hesiod was eventually transferred to a tomb located in the territory of the city of Orkhomenos in Boeotia (2.247-253), and the wording of an epigram inscribed on his tomb is quoted (2.250-254). Elsewhere too, it is reported that the corpse of Hesiod was transferred to a tomb located in the territory of the city of Orkhomenos (Tzetzes Life of Hesiod p. 51 ed. Wilamowitz; Aristotle, Constitution of the People of Orkhomenos F 565 ed. Rose).

This second version differs in some important details from a third version as reported by Plutarch (Banquet of the Seven Sages 19 p. 162c-e): according to that third version, the corpse of Hesiod was not relocated at the city of Orkhomenos but remained hidden in a tomb located in West Locris, at the precinct of Zeus Nemeios. So, the myth about Hesiod as told in West Locris contradicted the myth about Hesiod as told at Orkhomenos in Boeotia. \{305|306\}

At one point in the Contest of Homer and Hesiod, in the first version of the myth as derived from Alcidamas, it is said that the murderers of Hesiod had sailed off with his corpse and had thrown it overboard on the high seas between Euboea and Locris (Vita 2.231-232). The 'Locris' that is mentioned here must be East Locris - not West Locris, which as we have seen was where Hesiod's corpse was buried according to the myth retold by Plutarch. But the localization of Hesiod's murder near East Locris may not necessarily be a mistake. ${ }^{88}$ Rather, this detail may stem from the version of the myth promoted by the people of Orkhomenos, for whom the tomb of Hesiod must not be localized in West Locris.

Such mutually contradictory claims concerning the corpse of Hesiod were tied to various different myths about the life of the poet, which in turn were tied to various different ritual practices involving the worship of Hesiod as a cult hero. ${ }^{89}$ And the morphology of these myths about the life of Hesiod is closely parallel to the morphology of other myths about the lives of other cult heroes. ${ }^{90}$ For example, the detail about the dolphins that rescue the corpse of Hesiod is closely parallel to a detail we find in the myth about the cult hero Melikertes / Palaimon, whose corpse is likewise rescued and carried ashore by a dolphin (Pausanias 1.44.8; scholia to Pindar, Hypothesis for the Isthmian Odes ed. Drachmann). ${ }^{91}$ On the beach where the corpse of Melikertes / Palaimon was reportedly deposited, visitors could see a pine tree and an altar sacred to this cult hero, whose corpse was said to be hidden inside an aduton 'inner sanctum' accessible only by way of an underground descent (Pausanias 1.44.8, 2.1.3) ${ }^{92}$ Such

\footnotetext{
${ }^{88}$ As claimed by West 2003:343n15.

${ }^{89}$ Nagy 1990b:48-50.

${ }^{90}$ Brelich 1958:322: "Così il poeta rientra perfettamente nella morfologia caratteristica dell'eroe."

${ }^{91}$ Pache 2004:138, 151-152.

${ }^{92}$ Pache 2004:152.
} 
myths about the corpses of cult heroes center on the mystical theme of the hero's resurrection after death. ${ }^{93}$

As we can see, then, from the conflicting details surrounding the death of Hesiod, different locales in Locris and in Boeotia had different myths about the life and times of this poet, and these myths were tied to rival hero cults that were anchored in these locales. So, we cannot $\{306 \mid 307\}$ speak of any single perspective - not to mention any single truth value inherent in these myths.

For the objective observer, the multiple truth values of these multiple "Life of Hesiod" myths need to be viewed from an empirical perspective, detached from the various different collective perspectives of ancient mythmaking. In objective terms, it is not a question of true or false storytelling in these myths. Rather, the storytelling of the various "Life of Hesiod" myths can be viewed as historical evidence for the varied reception of Hesiodic poetry by the various societies in which and through which this poetry was transmitted.

Here I come back to my earlier point about the need to view the "Life of Hesiod" traditions as historical evidence for the reception of Hesiodic poetry by the various societies in which and through which this poetry was transmitted. By now we see that the different hero cults of Hesiod as attested in different locales of Boeotia and elsewhere can be viewed as a significant aspect of the reception and transmission of Hesiodic poetry. An analogous point can be made about the various different hero cults of Homer as attested in different locales of Ionia, such as Smyrna, Chios, and even Delos. ${ }^{94}$ In the case of Chios, the reception and transmission of Homeric poetry can be linked not only with a local hero cult of Homer but also with the activities of an ancient confraternity of performers known as the Homeridai, who claimed to be descended from Homer as their cult hero. ${ }^{95}$ Similarly, the reception and transmission of Hesiodic poetry at Thespiai in Boeotia can be linked with the activities of a confraternity known as the sunthutai Mousōn Hēsiodeiōn 'fellow-sacrificers to the Hesiodic Muses' (IG VII 1785, third century BCE). ${ }^{96}$

There are traces of Hesiod's identity as a cult hero even within Hesiodic poetry. A case in point is the episode of his dramatized encounter with the local Muses of Mount Helicon in the Hesiodic Theogony (22-34). The details of this encounter are strikingly parallel with details we find concerning the encounter of the poet Archilochus with the local Muses of the island of

\footnotetext{
${ }^{93}$ For more on this mystical theme, see Nagy 2001:xv-xxii. On the application of this theme to Hesiod, see Nagy 1990b:50n45; also Scodel 1980, with special reference to an epigram reportedly inscribed on Hesiod's tomb, as quoted by Tzetzes Life of Hesiod p. 51.9-10 ed. Wilamowitz.

${ }^{94}$ Nagy 1996a:113n34.

${ }^{95}$ Nagy 1996a:113n33 and 2009:1§\$138-167.

${ }^{96}$ Nagy 1990a:29 (1§22) n66 and 1996a:113n34.
} 
Paros, as narrated in a document directly linked to the hero cult of Archilochus on that island. This document is the Mnesiepes Inscription (SEG 15.517), plausibly dated to the third century BCE, which memorializes the symbiotic worship of Archilochus as a cult hero with \{307|308\} the Muses as goddesses who share in the hero's cult. ${ }^{97}$ This inscription contains a myth telling about a mystical encounter between Archilochus and the Muses (column II verses 23 and following): ${ }^{98}$

It is nighttime in the countryside, and Archilochus is driving his father's cow to the city in order to sell it there. Along the way, he encounters a group of rustic women, who are the Muses in disguise. He proceeds to taunt them with derisive insults, and the disguised Muses respond by taunting him with their own derisive insults. In this carnivalesque setting, the Muses ask Archilochus to trade away the cow. Agreeing to do so if the price is right, Archilochus falls into a swoon; when he awakens, the rustic women are gone, and so, too, is the cow; but in its place Archilochus finds the lyre of poetry, a symbol of his transformation from cowherd to poet.

In the case of Hesiod, we find a comparable narrative embedded in the Theogony:

It is nighttime when Hesiod experiences his own encounter with the Muses (10) while he is tending his sheep (23). He too is taunted with derisive insults, as the Muses say to him: 'shepherds living in the fields, base objects of reproach, mere bellies!' (26). And he too receives from the Muses a gift that symbolizes his transformation into a poet. In this case, the gift is a scepter made from the wood of the laurel (30-31). This scepter made of laurel, which is fit for a king, is a symbol of Hesiod's transformation from shepherd to poet. And the poetry of this poet, which is a theogony, is royal poetry fit for a king - hence the scepter; by the same token, this theogony is also mantic poetry fit for a seer - hence the wood of the laurel. ${ }^{99}$

Besides such internal evidence for a parallelism between Archilochus and Hesiod as cult heroes, there is also external evidence. For example, Plutarch speaks of these two figures as parallel cult heroes when he mentions, in passing, the two of them together (Life of Numa 4.9). ${ }^{100}\{308 \mid 309\}$

\footnotetext{
${ }^{97}$ Clay 2004:10-13.

${ }^{98}$ Commentary in Nagy 1990b:49.

${ }^{99}$ On the mantic as well as royal dimensions of theogonic poetry, see Nagy 1990b:58-61.

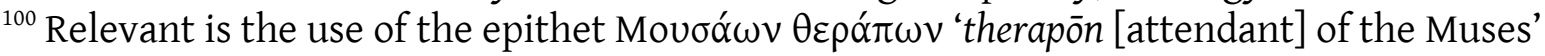
with reference to the generic poet in the Hesiodic Theogony (100), which is comparable to the use of the same epithet in a myth concerning the death of Archilochus (as reported by Galen Protreptikos 5): see Nagy 1979:301-302 (18\$1).
} 


\section{The pan-Hellenized Hesiod of Hesiodic poetry}

We might have expected the Hesiodic Theogony, as a theogony, to validate the kingship of a king. From an anthropological view, that is the basic function of a localized theogony, to validate kings. ${ }^{101}$ In the case of the Theogony, however, we find no such localization. This Hesiodic composition validates no local king. Instead, it validates the kingship of Zeus who lives on Olympus. When the Theogony describes an ideal king (80-83), the one thing missing in the description is a scepter. We see a significant absence here, since the scepter is not to be found in the hands of the idealized king: rather, Hesiod is the one who receives the scepter in the Theogony (30-31). Earlier, we saw that the scepter is a symbol of Hesiod's transformation from shepherd to poet, and that the poetry of this poet is royal poetry fit for a king. But there is more to it: the former status of Hesiod as a humble shepherd is actually a part of the symbolism. In the metaphorical world of the Indo-European and Near Eastern poetic traditions that merge with each other in the social context of early Greek civilization, kings become leaders of men just as shepherds become leaders of their flocks, and the metaphor of the shepherd-king comes to life in myths about transformations of humble shepherds into mighty kings. ${ }^{102}$ The story of Hesiod's transformation in the Theogony is analogous: he receives the scepter from the Heliconian Muses because he is the one whom the goddesses inspire to become the spokesman for the kingship of Zeus on Olympus. And these Muses of Helicon become Muses of Olympus because Hesiod the poet becomes pan-Hellenized in the process of validating the kingship of Zeus on Olympus.

An analogous point can be made in the case of the Hesiodic Works and Days, which represents a form of poetry that concentrates on the symmetry of moral correctness with ritual correctness. As in the case of the Theogony, we might have expected the Works and Days to be a localized composition, grounded in the customary laws of Hesiod's own homeland in Boeotia. But there is no such localization. The perspective of the Works and Days is pan-Hellenic in scope, like the perspective of the Theogony. ${ }^{103}$ And Hesiod's quarrel with his brother Perses is not some kind of local dispute based on localized legal concerns: it is a universalized conflict based on an absolutized distinction between what is $\{309 \mid 310\}$ morally right and what is morally wrong for any Greek-speaking community: even the name of Perses conveys the negative side of this universalized conflict: it is derived from the verb perthein 'destroy', which is conventionally applied in moralizing poetic instructions warning about the destruction of communities that choose what is morally wrong over what is morally right (an outstanding example is the warning expressed in Theognis 1103-1104). ${ }^{104}$

\footnotetext{
${ }^{101}$ Nagy 1990b:46-47, 56-61.

${ }^{102}$ West 1997:226-227.

${ }^{103}$ Detailed argumentation in Nagy 1990b:63-79.

${ }^{104}$ Nagy 1990b:75.
} 


\section{"Life of Hesiod" traditions: a brief overview}

An aspect of reception and transmission in oral traditions is the making of myths about the performances of these traditions. Such myths, as we have seen, are exemplified in the "Life of Hesiod" traditions. Outside of the Greek evidence, the most salient examples of comparable "Lives of Poets" myths can be found in medieval Provençal and medieval Persian poetic traditions. ${ }^{105}$

And the persona of Hesiod keeps changing within these "Life of Hesiod" traditions. At one extreme, he seems to be permanently stationary at Ascra, while at another extreme he seems to be ever on the move. He starts as a shepherd who is most knowledgeable about farming as well as herding and who declares that he has never sailed on the open sea. But then he goes to a poetic contest, crossing the strait at Aulis in Boeotia. And the next thing you know, he is a wandering poet, who travels from city to city and competes with other poets in public performances. He even makes an appearance in the most maritime of all places, the island of Delos, where he competes with Homer himself.

As we see from the Contest of Homer and Hesiod (Vita 2), Hesiod was identified with kings while Homer was identified with the people. A case in point is the audience attending the primal contest between Homer and Hesiod at Chalkis in Euboea: this audience, who are described simply as 'the Hellenes', enthusiastically acclaim Homer as the true winner over Hesiod, but the king presiding over the event overrules the will of the 'Hellenes' and awards the victory to Hesiod instead (Vita 2.176-179, 205-210). Hesiod's association with royal authority is indicated even by the $\{310 \mid 311\}$ internal evidence of Hesiodic poetry: his poetic authority is pictured as a substitute for royal authority in both the Theogony and the Works and Days. ${ }^{106}$

The idea of Hesiod as a royalist would be most acceptable in the democratic era of Athens, at a time when Homeric poetry eclipsed Hesiodic poetry as the program, as it were, of the Panathenaia. In the postdemocratic era of antiquarian research, however, the royalism of Hesiod is shaded over and his anti-royalism is highlighted. According to Pausanias (1.2.3), for example, Hesiod's professed reluctance to travel and his strong attachment to a stationary way of life in the countryside can best be explained as a sure sign that this poet has completely detached himself from the company of kings. That kind of man is the Hesiod we know from the history of Hesiodic reception that persists into our own times.

\footnotetext{
${ }^{105}$ On the Provençal traditions, see Nagy 1990a:80 (2§50) n140; on the Persian, see Davidson 2001.

${ }^{106}$ Nagy 1990b:52-53.
} 


\section{Bibliography}

Allen, T. W., ed. 1912. Homeri Opera. Vol. 5. Hymns, Cycle, Fragments. Oxford.

Aloni, A. 1989. L'aedo e i tiranni: Ricerche sull'Inno omerico ad Apollo. Rome.

Athanassakis, A. N. 1992. “Introduction.” Essays on Hesiod I (ed. A. N. Athanassakis), Ramus 21:110.

Bechtel, F. 1924. Die griechischen Dialekte. III: Der ionische Dialekt. Berlin.

Berenson Maclean, J. K., and E. B. Aitken., eds 2001. Flavius Philostratus, Heroikos. Atlanta, GA.

Calame, C. 2001. Choruses of Young Women in Ancient Greece: Their Morphology, Religious Role, and Social Function (tr. D. Collins and J. Orion). 2nd ed. Lanham, MD.

Chantraine, P. 2009. Dictionnaire étymologique de la langue grecque: histoire des mots (ed. J. Taillardat, O. Masson, and J.-L. Perpillou), with a supplement Chroniques d'étymologie grecque 1-10 (ed. A. Blanc, Ch. de Lamberterie, and Jean-Louis Perpillou). Paris. Abbreviated DELG.

Clay, D. 2004. Archilochos Heros: The Cult of Poets in the Greek Polis. Washington, DC and Cambridge, MA.

Clay, J. S. 1989. The Politics of Olympus: Form and Meaning in the Major Homeric Hymns. Princeton.

Clay, J. S. 2003. Hesiod's Cosmos. Cambridge.

Colbeaux, M.-A. 2005. Raconter la vie d'Homère dans l'antiquité. Édition commentée du traité anonyme, "Au sujet d'Homère et d'Hésiode, de leurs origines et de leur joute," e de la "Vie d'Homère" attribué à Hérodote. Dissertation, Université Charles de Gaulle - Lille III.

Collins, D. 2004. Master of the Game: Competition and Performance in Greek Poetry. Washington, DC and Cambridge, MA.

Davidson, O. M. 2001. "Some Iranian Poetic Tropes as Reflected in the 'Life of Ferdowsi' Traditions.” In Philologica et Linguistica: Festschrift für Helmut Humbach (ed. M. G. Schmidt and W. Bisang) supplement: 1-12. Trier.

Detienne, M. 1994. Les Maîtres de vérité en Grèce ancienne. Revised ed., with a new preface: "En ouverture: retour sur la bouche de la Vérité" (5-31). Paris. Trans. by J. Lloyd. as The Masters of Truth in Archaic Greece. New York. 1996. 
Di Gregorio, L., ed. 1975. Scholia vetera in Hesiodi Theogoniam. Milano.

Householder, F. W. and G. Nagy. 1972. Greek: A Survey of Recent Work. The Hague.

How, W. W., and J. Wells. 1912. A Commentary on Herodotus. I/II. Revised 1928. Oxford.

Larson, S. 2000. "Boiotia, Athens, the Peisistratids, and the $<<$ Odyssey >>'s Catalogue of Heroines." Greek Roman and Byzantine Studies 41:193-222.

Lord, A. B. 1960 [2000]. The Singer of Tales. Harvard Studies in Comparative Literature 24. 2nd ed. with introduction by S. Mitchell and G. Nagy [vii-xxix]. Cambridge, MA.

Martin, R. P. 1992. “Hesiod's Metanastic Poetics.” Essays on Hesiod I (ed. A. N. Athanassakis), Ramus 21:11-33.

Martin, R. P. 2000a. "Wrapping Homer Up: Cohesion, Discourse, and Deviation in the Iliad." Intratextuality: Greek and Roman Textual Relations (ed. A. Sharrock and H. Morales) 43-65. Oxford.

Martin, R. P. 2000b. "Synchronic Aspects of Homeric Performance: The Evidence of the Hymn to Apollo." In Una nueva visión de la cultura griega antigua hacia el fin del milenio (ed. A. M. González de Tobia) 403-432. La Plata.

Most, G. W., ed. and trans. 2006a/b. Hesiod: Theogony, Works and Days, Testimonia / The Shield, Catalogue of Women, Other Fragments. Cambridge, MA.

Muellner, L. 1996. The Anger of Achilles: Mênis in the <<Iliad >>. Ithaca, NY.

Nagy, G. 1982. “Hesiod.” Ancient Writers (ed. T. J. Luce) 43-73. New York.

Nagy, G. 1990a. Pindar's Homer: The Lyric Possession of an Epic Past. Baltimore, MD. <<http://www.press.jhu.edu/books/nagy/PHTL/toc.html>> (1997).

Nagy, G. 1990b. Greek Mythology and Poetics. Ithaca, NY.

Nagy, G. 1992. "Authorisation and Authorship in the Hesiodic Theogony.” Essays on Hesiod II (ed. A. N. Athanassakis), Ramus 21:119-130.

Nagy, G. 1996a. Poetry as Performance: Homer and Beyond. Cambridge.

Nagy, G. 1996b. Homeric Questions. Austin, TX.

Nagy, G. 1996c. “Autorité et auteur dans la Théogonie hésiodique.” Le métier du mythe. Lectures d'Hésiode (ed. F. Blaise, P. Judet de La Combe, P., and P. Rousseau) 41-52. Paris. 
Nagy, G. 2001. “The Sign of the Hero: A Prologue.” In Berenson Maclean and Aitken 2001:xv-xxxv.

Nagy, G. 2002. Plato's Rhapsody and Homer's Music: The Poetics of the Panathenaic Festival in Classical Athens. Cambridge, MA / Athens.

Nagy, G. 2003. Homeric Responses. Austin, TX.

Nagy, G. 2004a. "L'aède épique en auteur: la tradition des Vies d'Homère." Identités d'auteur dans l'Antiquité et la tradition européenne (ed. C. Calame, and R. Chartier) 41-67. Grenoble.

Nagy, G. 2004b. "Transmission of Archaic Greek Sympotic Songs: From Lesbos to Alexandria." Critical Inquiry 31:26-48.

Nagy, G. 2005. “The Epic Hero.” A Companion to Ancient Epic (ed. J. M. Foley) 71-89. Oxford. Updated version at:

http://chs.harvard.edu/publications.sec/online_print_books.ssp/gregory_nagy_the_e pic/bn_u_tei.xml_5

Nagy, G. 2006. “Homer's Name Revisited." La langue poétique indo-européenne: actes du Colloque de travail de la Société des Études Indo-Européennes (Indogermanische Gesellschaft / Society for Indo-European Studies), Paris, 22-24 octobre 2003 (ed. G.-J. Pinault and D. Petit) 317-330. Collection linguistique de la Société de Linguistique de Paris 91. Leuven and Paris.

Nagy, G. 2008a. Homer the Classic. Washington, DC and Cambridge, MA.

Nagy, G. 2008b. Greek: Toward an Updating of a Survey of Recent Work. Washington, DC and Cambridge, MA. An updating of Nagy 1972.

Nagy, G. 2009. Homer the preclassic. Berkeley / Los Angeles, CA.

Nietzsche, F. 1870 / 1873. "Die Florentinische Traktat über Homer und Hesiod, ihr Geschlecht und inhren Wettkampf." Rheinisches Museum 25:528-540 / 28:211-249.

Nietzsche, F. 1871. Edition of <<Contest of Homer and Hesiod >>. Acta Societatis Philologiae Lipsiensis 1:1-23.

Pache, C. O. 2004. Baby and Child Heroes in Ancient Greece. Urbana and Chicago.

Parry, A., ed. 1971. The Making of Homeric Verse: The Collected Papers of Milman Parry. Oxford.

Pertusi, A., ed. 1955. Scholia vetera in Hesiodi Opera et Dies. Milano.

Rosen, R. M. 1990. “Poetry and Sailing in Hesiod's Works and Days.” Classical Antiquity 9:99-113. 
Scodel, R. 1980. “Hesiod Redivivus.” Greek Roman and Byzantine Studies 21:301-320.

West, M. L. 1985. The Hesiodic Catalogue of Women. Oxford.

West, M. L. 1997. The East Face of Helicon: West Asiatic Elements in Greek Poetry and Myth. Oxford.

West, M. L., ed. and trans. 2003. Homeric Hymns, Apocrypha, Lives. Cambridge, MA.

Wilamowitz-Moellendorff, U. von, ed. 1916. Reprinted 1929. Vitae Homeri et Hesiodi. Berlin.

Winter, J. G. 1925. “A New Fragment on the Life of Homer.” Transactions of the American Philological Association 56:120-129. 